\title{
Ancient Egyptian Seals and Scarabs
}

\author{
Amelia Carolina Sparavigna
}

2009, Torino, Italy 
Amelia Carolina Sparavigna is assistant professor from 1993 at the Polytechnic of Torino, Italy. She gained her Bachelor Degree in Physics from the University of Torino in 1982, and the Doctoral Degree in 1990. She is co-author of more than 80 publications on international journals. Her research activity is on subjects of the condensed matter physics, in particular the thermal and charge transport in solids and in polymeric networks. She has a passion for archaeology.

Editore: Lulu.com

Copyright: @ 2009 A.C.Sparavigna, Standard Copyright License

Lingua: English

Paese: Italia 


\title{
CONTENTS
}

\author{
INTRODUCTION \\ THE ANCIENT SEALS \\ THE SHAPES OF EGYPTIAN SEALS \\ TYPES OF SCARABS \\ MATERIALS FOR SEALS \\ THE DEVELOPMENT OF SEALS \\ RELIGIOUS BACKGROUND \\ HISTORICAL IMPORTANCE OF SCARABS \\ ARTS IN SCARABS \\ ICONS ON SEALS \\ THE "DJED" \\ THE URAEUS AND THE EYE OF HORUS \\ SPHINXES AND FANTASTIC ANIMALS \\ SCARABS OF THE MIDDLE BRONZE AGE (HYKSOS SCARABS) \\ SYMMETRIES ON SEALS \\ ROTATIONAL SYMMETRY \\ SCARABS AND SYMMETRIES \\ References \\ Conventional Egyptian Chronology
}




\section{INTRODUCTION}

"... Queen Tera had power to compel the Gods. This, by the way, was not an isolated belief in Egyptian history; but was different in its cause. She had engraved on a ruby, carved like a scarab, and having seven stars of seven points, Master Words to compel all the Gods, both of the Upper and the Under Worlds." This is the description of "The Jewel of the Seven Star", the Scarab seal which appears in the homonymous novel, by Bram Stoker, 1903. The story is about an archaeologist's plot to revive Queen Tera, an ancient Egyptian mummy.

As well described in this short paragraph by Stoker, the Egyptian Scarabs were for their ancient possessors, mainly amulets with powerful images or spells. To the moderns, the Scarab seals are objects of interest, either as emblems of Egyptian religion or specimens of the Egyptian art, while to the archaeologist and historian they are often useful as evidences.

We will discuss seals in some of their aspects, and we will show images of some scarabs from the collection at the Egyptian Museum of Torino. A particular aspect of scarab seals, never investigated before, will be also considered: the presence of symmetries in images engraved on them.

Let us start with a short discussion on the role of seals in ancient societies.

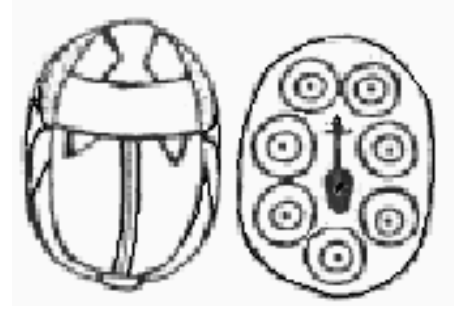

\section{THE ANCIENT SEALS}

Sealing is the impression made by the impact of a hard-engraved surface on a softer material, such as clay or wax. The word seal (Latin "sigillum", old French "scel") refers either to the device or to the impression. Ancient stamp seals and cylinder seals were made of a hard material, used to press an engraved figure or a short inscription into soft clay. In ancient times, seals were used for the 
securing of bags, baskets, jars, etc. The sealing method was either to shape clay over the container stopper or make a fastening with cord and place clay around the knot. The impressed seals on clay were both used to avoid tampering and as a method of identification of content or owner.

The seals were of two main types, the cylinder and the stamp. The cylinder first appeared in Mesopotamia in the late 4th millennium BC, then widespread in Syria and Egypt and in the Aegean area. Stamp seals preceded cylinders, first appearing in Mesopotamia in the 5th millennium BC. Early stamp seals were also used in Iran, northern Syria, and Anatolia (4th and 3rd millennia BC). In Egypt, the scarab seals largely replaced cylinder seals early in the 2nd millennium BC and continued as the main type. They were replaced by the signet ring in Roman period. In the Aegean, stamp seals were used throughout the 2nd and much of the 1st millennium BC, until the signet ring became dominant, in Hellenistic and Roman times ${ }^{1}$.

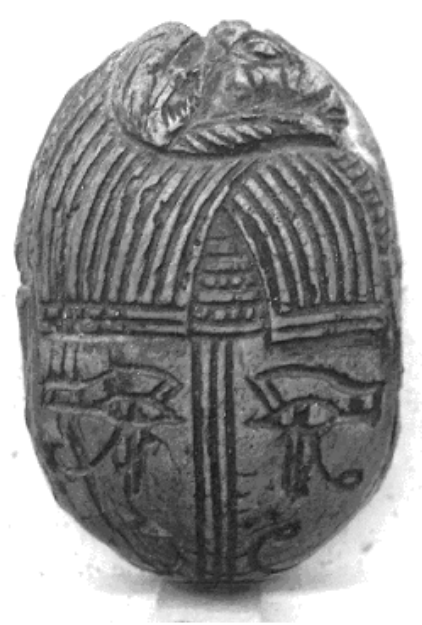

A Scarab seal with a decorated back (Egyptian Museum, Torino)

For Egyptians, the Scarab seal was not only an impression seal: it was also an amulet with images and symbols engraved to protect the owner. Scarabs were

\footnotetext{
${ }^{1}$ From the Encyclopaedia Britannica
} 
used extensively in Egypt, but they became quite popular and produced also outside of Egypt.

In fact, stamp seals with round or ovoid shapes are considered as Scarab seals, even when the round back of the object is not precisely shaped as a scarab. They are named Scaraboid seals. In the case of Egyptian Scarabs, books reporting the collections are available, many on public domain ${ }^{2}$.

Images on seals are of several types. In the case of Egyptian Scarabs, we find inscriptions with names of kings and gods, human figures and animals. Coils and entanglements of cords are characteristic of the Middle Kingdom Period. Among images of animals, goats and antelopes had a great success during the Hyksos period, because Hyksos took the antelope form of the Egyptian god Seth to represent their own deity ${ }^{3}$.

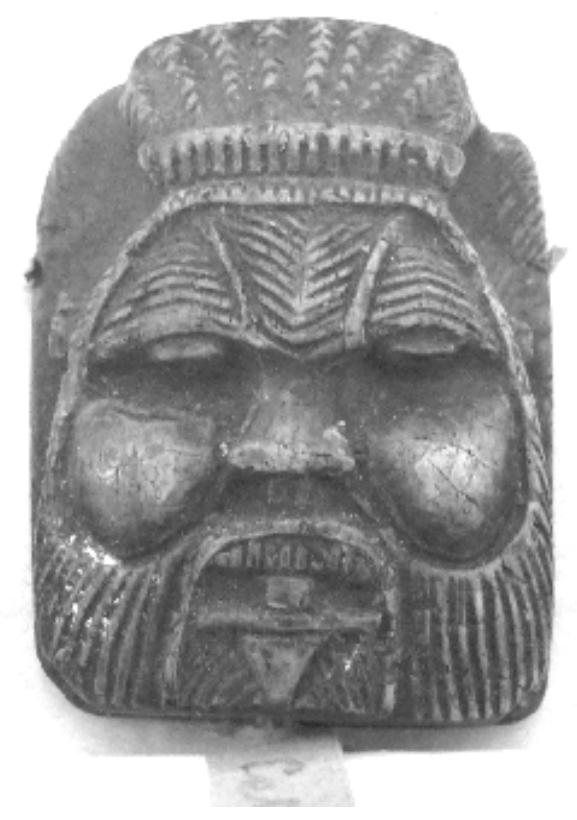

Scaraboid seals have back with various forms, such as that of a human head (Egyptian Museum, Torino)

${ }^{2}$ Among books on scarab collections, we have those by: F. Magnarini (2004), J. Ward (1902), K.H. Hall (1913), P.E. Newberry (1907)

${ }^{3} \mathrm{~F}$. Magnarini (2004) 


\section{THE SHAPES OF EGYPTIAN SEALS}

The objects that we can find in collections of ancient Egyptian seals, can be with a cylinder or a button form. A cylinder seal is cylindrically made to be rolled over wax or clay, that is material which takes its impression. A button seal is instead a stamp seal, often mounted on a signet-ring. The Scarab or Scaraboid seals were primarily intended to be strung or to hang from a necklace, exactly as a modern charm.

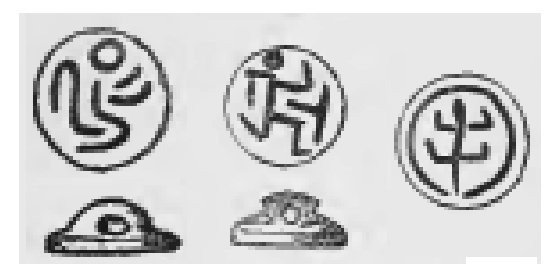

Button seals

The Scarab is an amulet, representing the sacred beetle (Scarabaeus aegyptiorum), emblem of Khepera (also spelled Khepri), the creator Sun-god. This amulet was adapted for use as a seal, with the signet cut on its base. When not too large, it could be mounted as the bezel of a ring.

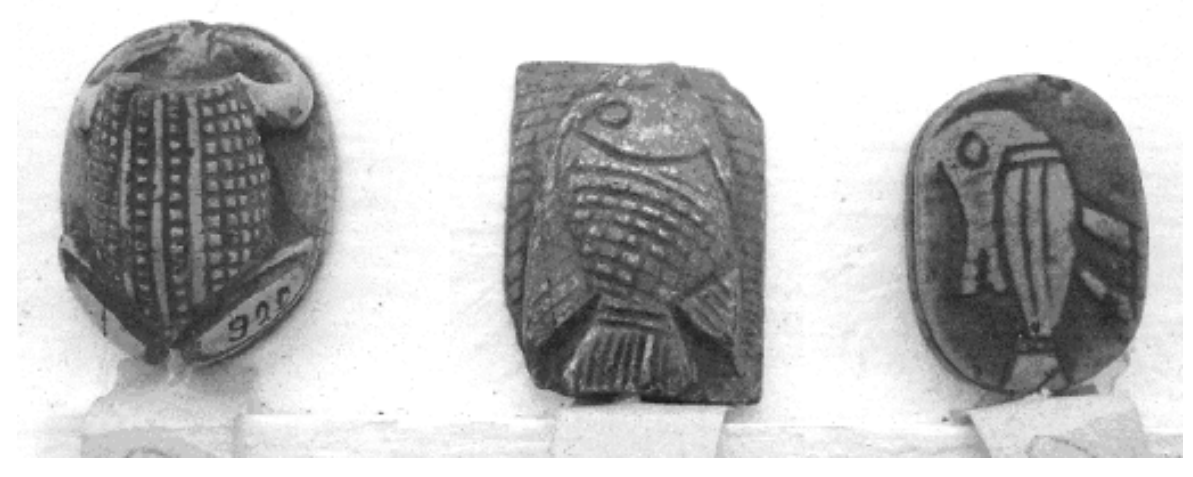

A frog, a fish and a waterfowl (Egyptian Museum, Torino). Seal-amulets can also have the forms of frogs, flies, rats, hedgehogs, and so on (Hall, 1913) 
The Scaraboid seal is a modification of the Scarab, retaining more or less the ovoid form of the engraved base, while the back was either absolutely plain or could be shaped in various forms. The Cowroid seal has a lentoid shape, originally imitating the form of a cowry-shell, but afterwards losing all trace of this form. Plaques are plaque-shaped amulets, inscribed in the same manner as the Scarabs. Of course, it is possible to find combinations of the Scaraboid and the Plaque forms.

Scarabs are perforated for stringing. When worn as amulets, they were usually strung on necklaces, or suspended from a chain. Even the Cylinder-seal is perforated, so that it might be slung on a necklace. When intended to be a bezel of a signet-ring, the Scarab or Plaque was perforated and was secured to the ring by means of a metal wire passing through the perforation.
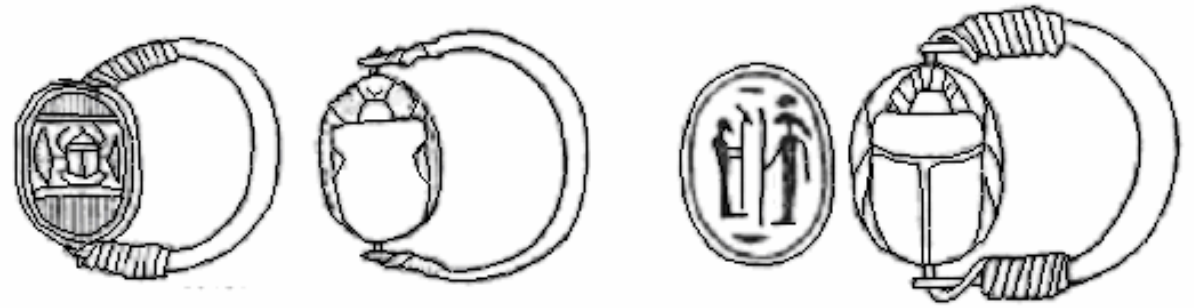

Signet-rings with a scarab as bezel, secured to the ring by a wire.

With the exception of the larger Scarabs, which were placed as amulets on the bodies of the dead, objects were either perforated or provided with some other means of being strung or suspended to chains. They were therefore, all originally intended to be worn upon the person.

The common characteristic of all these various objects was that they were used as seals or adapted to be used for sealing. The Scarab, originally a religious amulet, was adapted to be used as a seal. The result was that those Scarabs or derivatives (Scaraboids, Cowroids and Plaques), which were never intended to be anything else than amulets, have inscriptions which are appropriate to a 
seal. Other Scarabs continued to be purely amulets: these are the Heartscarabs, which often bore no inscription or ornament at all. For what concerns the cylinder-seals, at the origin they were just seals. In later periods, they acquired the amulet's feature too.

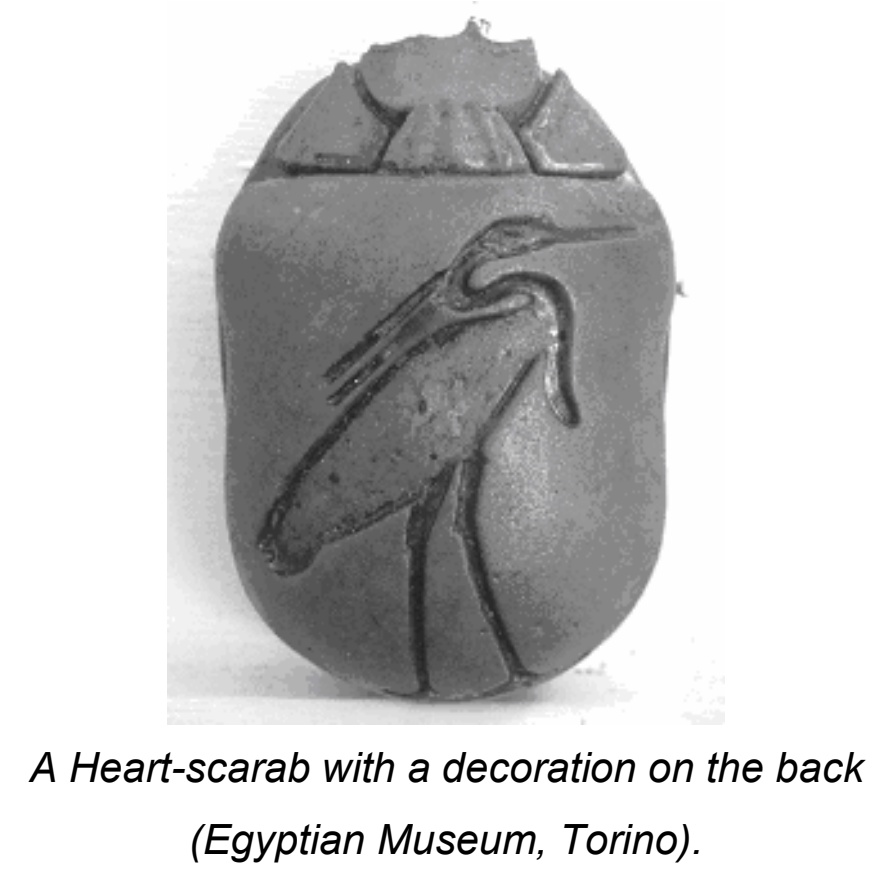

Of all the productions of small objects from the Egyptian artists, the Scarab was characteristically Egyptian, and greatly appreciated among the surrounding populations. In Palestine, Scarabs of the XIlth dynasty and of all the later periods are found in tombs and other sites. In Phoenicia the Scarab was regularly imitated by the local artists. Phoenician Scarabs have been found as far West in Etruria, and at Tharros in Sardinia.

The Scarab, introduced from Phoenicia, became popular in Greece. These Greek Scarabs were Greek-made, and their designs were purely Greek. These foreign owners or makers of Scarabs knew none of the religious Egyptian ideas. To them, they were objects, often beautifully made or of beautiful colour, which might be used as seals, possessing some magic virtues. 


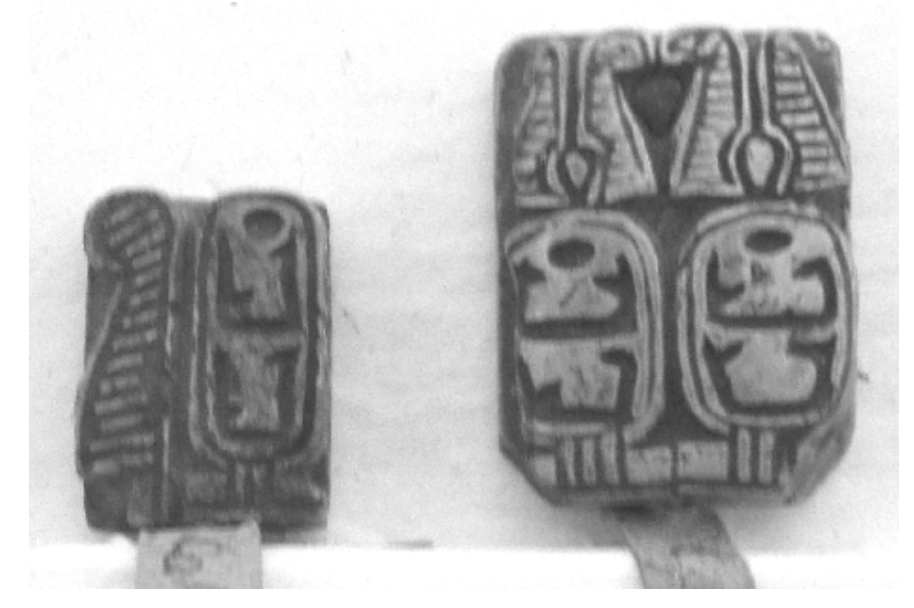

On these plaques there are the feathers of Maat. This feather represents truth, justice, morality and balance. It is the king who upholds Maat. When the king dies, Maat is lost and only the coronation of a new king restores Maat (Egyptian Museum, Torino).

\section{TYPES OF SCARABS.}

The types of Scarabs seals are far more diverse and complicated, due to the possibilities to represent wings, head and legs of the insect. The Scarabmakers of one period did not make their Scarabs exactly like those of another. For instance, at one time they cut the legs very carefully, at another the legs disappeared. Moreover, at the same period many varieties of Scarab could exist side by side.
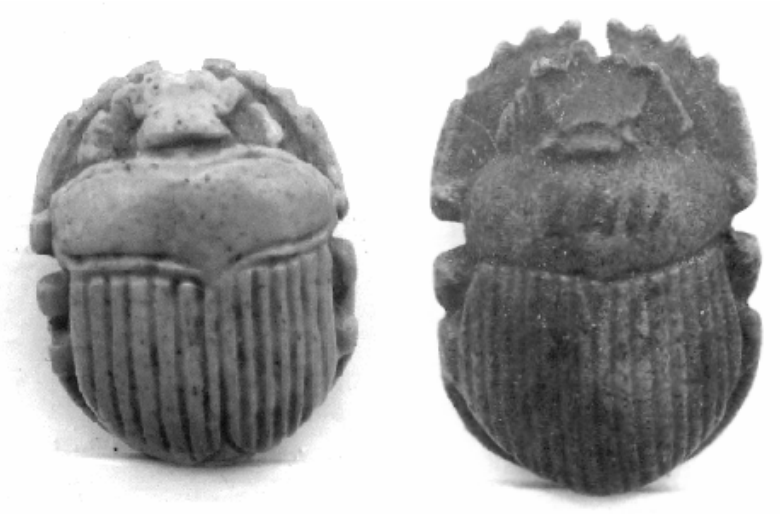

The scarab can have a simple or elaborated naturalistic form (Egyptian Museum, Torino) 
The varieties of Scarabs can be arranged in many groups ${ }^{4}$. The groups are designated by letters of the alphabet. The first main division is according of a more or less naturalistic type. The more naturalist group has been designated A. Those that follow, from $B$ to $M$, run down the complete range of types from the earlier Scarabs to those of the late periods. The Scarabs of Class $\mathrm{N}$ are peculiar because they have no base, and, therefore, they have lost the seal feature but were purely amulets.

The large Heart-scarabs, which were purely amulets, with inscriptions incised in the manner of seals, do not differ from the ordinary naturalistic Scarabs of Class A. It is to be understood that these types very often combine.

\section{MATERIALS FOR SEALS.}

The first used and always the most generally-used material was steatite, a soft grey schistose stone (silicate of magnesium). This stone, which is found also in Greece, was early used in both countries for the easy making of vases and other objects for which stone was good.

The natural colour of the stone was usually a greyish-white, though sometimes it was found of a dark hue. The light natural colour of the stone was not appreciated for the production of Scarabs, and then Egyptians hid it at first by a black smoke-pigment, then by means of a blue or green glaze. The art of glazing had been invented at the beginning of the first dynasty, and was applied to pottery (the characteristic Egyptian glazed pottery, or faience, is well known). There are not any glazed Cylinders or seals, till about the time of the $V$ th dynasty. After that time the use of the glazed material became the rule and lasted till the end.

The glaze was also a protection to the soft steatite material, which would be quickly damaged in the case of a much-used seal. Many of the unglazed Cylinders of the first dynasty are almost illegible from this cause. The firing, necessary for the fixing of the glaze, had a hardening action upon the steatite. At the present day, many Scarabs have lost the outer glaze for decomposition.

\footnotetext{
${ }^{4}$ K.H. Hall (1913)
} 
It remains on them a brittle substance which, at a first glance, is easy mistaken for ivory.

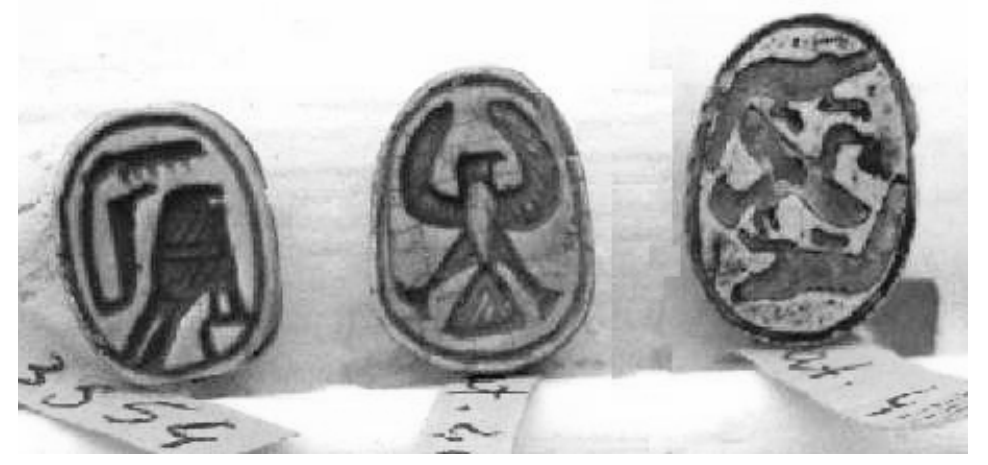

The Scarab in the middle has preserved its blue faience glazing on it (Egyptian Museum, Torino).

It was during the reign of Thothmes I that blue and green faience Scarabs become usual. Under the XIXth dynasty the popularity of faience continued, though colours degenerated. This degenerative process had the result that the fashion of the faience Scarabs went out under the XXth dynasty. It had revival under the Saites ${ }^{5}$.

To use a faience Scarab as a seal was difficult, as the material was too easily breakable. As discussed by Hall (1913), it is then significant that this faience material was generally used from the XVIIIth dynasty, when the amuletic character of the Scarab had practically extinguished its use as a seal. Under the XIIIth dynasty, when Scarabs were still regarded as amulets and as seals as well, both Scarabs of hard glazed steatite and Scarabs of hard stones that needed no glazing were produced.

${ }^{5}$ The Twenty-sixth Dynasty of Egypt was the last native dynasty to rule Egypt before the Persian conquest in $525 \mathrm{BC}$ (although others followed). The Dynasty's reign (c. 685-525 BC) is also called the Saite Period after the city of Sais, where its pharaohs had their capital, and marks the beginning of the Late Period of ancient Egypt. 


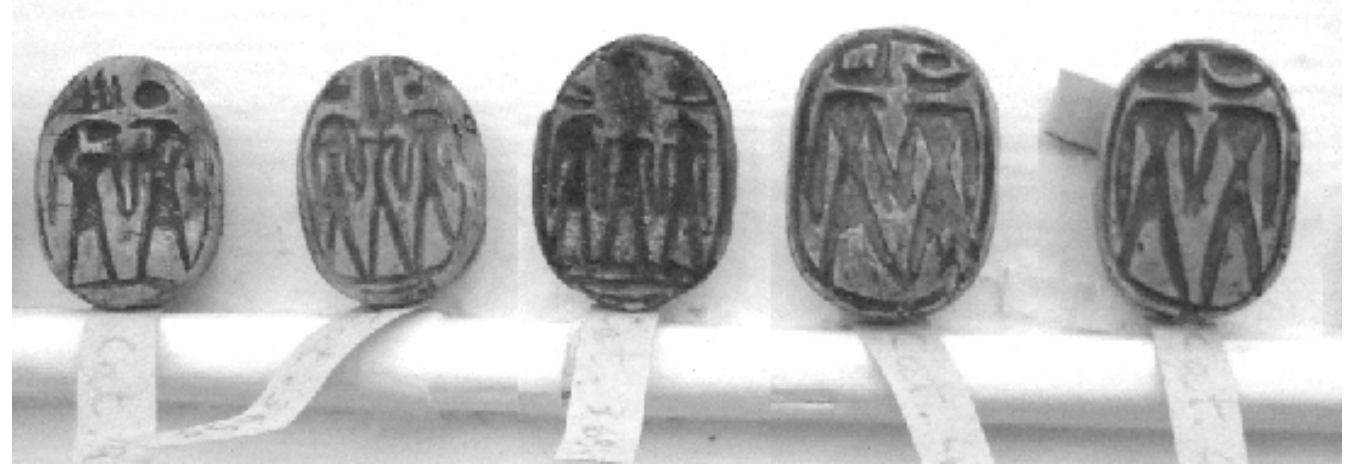

Gods on seals (Egyptian Museum, Torino)

Stones, harder than steatite, were utilized for the manufacture of Seals too. Under the XIlth dynasty the idea of utilizing hard stones spread. It was used in particular the Egyptian amethyst. Most of the amethyst Scarabs and amethyst beads are of this dynasty. Usually the base was bearing no inscription, the intention being to cover it with a gold plate on which the inscription could be marked. Of course, amethyst Scarabs with inscriptions cut on their bases are also known. With amethyst, it comes in fashion green feldspar, dark green jasper, green basalt and the very hard obsidian.

In Egypt the metals were more commonly used for the accessories of the seal than for the seal itself. It was the ring in which the Scarab was mounted rather than the Scarab itself that was made of gold, silver, or bronze. Nevertheless, exceptions occur in all the periods. Gold and electrum, more rarely silver ${ }^{6}$, were used under the XIIth dynasty to plate the bases of amethyst, obsidian, or jasper Scarabs. There are gold and even several silver Signet-rings, which show that the metal seal was usually made in the form of the Ring-signet.

${ }^{6}$ Under the XIXth dynasty, Egyptian had friendly relations with the Hittites of Asia Minor. Egyptians gained free access to Anatolian silver mines, and then silver ceased to be so rare, as it had previously been. In earlier periods, silver was by far more valuable than gold. 
Other materials used for seals were glass, wood, ivory and amber. True glass seems to have been invented in Egypt during the period of the Middle Empire, probably towards its end. The glass invention was a development from the art of glazing, which had been known as early as the first dynasty. To the middle of the XVIIIth dynasty may be dated Scarabs of opaque glasses, usually of a light blue colour, sometimes dark blue, to imitate turquoise and lapis respectively.

Wood was, as it is natural, one of the first materials used for the manufacture of seals. Many of the Cylinder-seals of the earliest dynasties are wooden. But later on the use of this material was abandoned for Cylinders and Scarabs seem never to have been made of it.

Ivory was rarely used for the manufacture of objects. Only in the period from the Vth to the XIlth dynasty, ivory was used for making of small objects, but a few Scarabs can be found. Bone, a material rarely used in Egypt, was never employed for the manufacture of any of these objects. Amber is naturally very rare. It is perishable and then very seldom used to make Scarabs of.

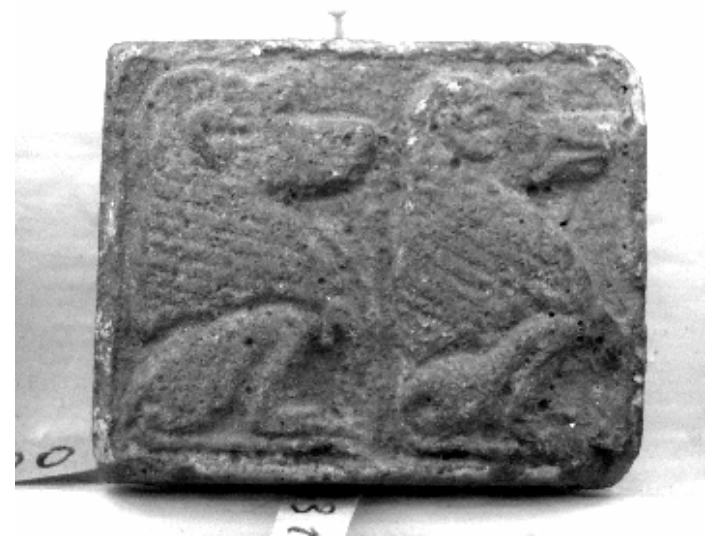

A small plaque with two monkeys on its back (Egyptian Museum, Torino).

\section{THE DEVELOPMENT OF SEALS.}

The oldest among the objects previously described is the Cylinder Seal, the earliest form of seal in Egypt. It was of the same form as the typical Babylonian Cylinder seal. As told by Hall (1913), the shape could suggest a connection 
between civilizations, but Cylinder seals were used in Egypt by the Predynastic population, and then it is difficult to argue possible foreign influences in that period. Cylinders may perhaps have originated in Egypt itself.

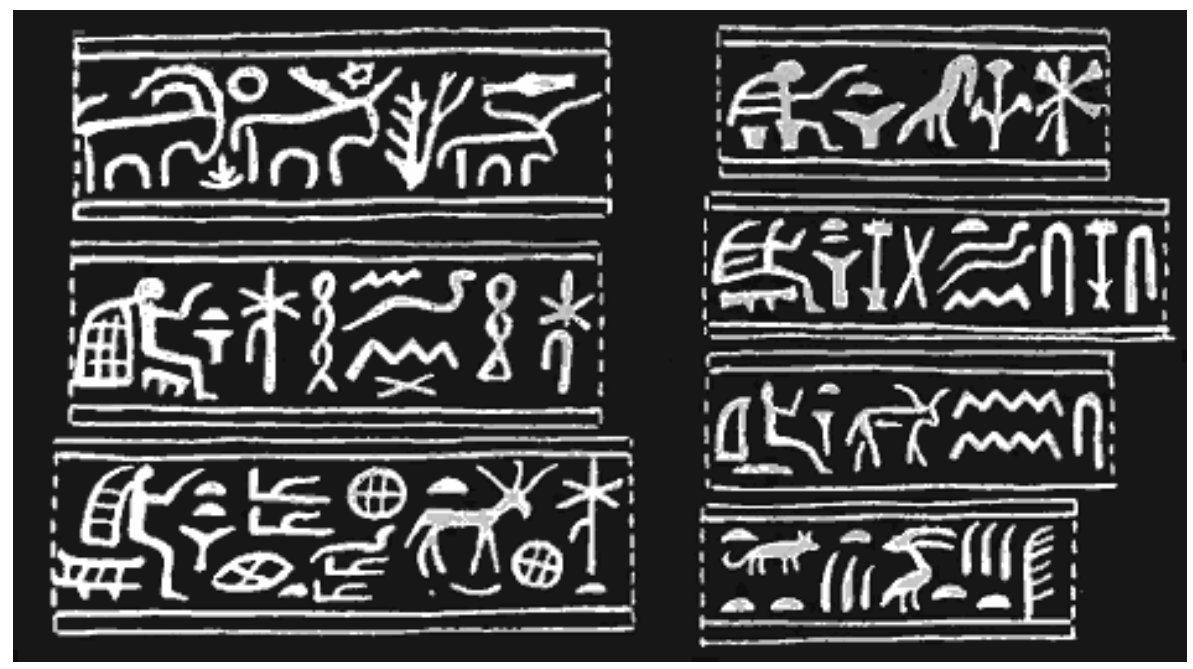

Pre-dynastic cylinder seal impressions, with personal names written in primitive ideographic characters.

The earliest Egyptian Cylinders are of wood, may be the development of cylinders obtained from pieces of reed on which primitive ideographic signs were cut. Very soon ivory was used, and then the soft stone, steatite. This material is the usual material of most of the Cylinders, which survived from the times of earliest dynasties. Under the XIlth dynasty, the Cylinder-seal was beginning to become simply an amulet bearing the name of the king, which was popularly considered to be of great magical protective power. Under the XVIIIth dynasty Cylinders, both simple seals and amulets, occur, though they are rare: afterwards they practically disappear ${ }^{7}$.

${ }^{7}$ K.H. Hall (1913) 

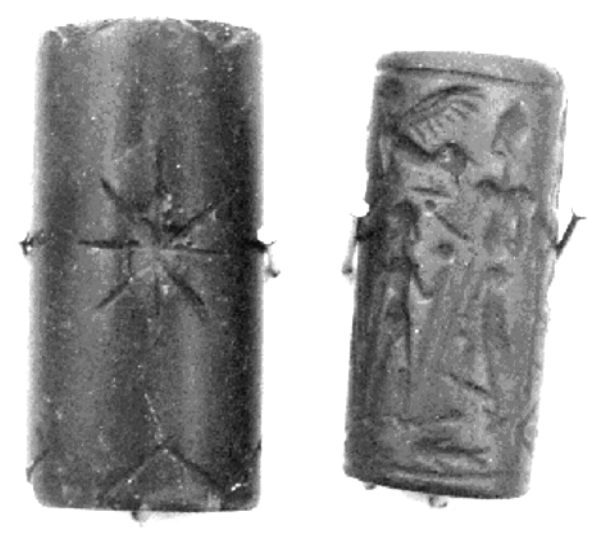

Two cylinder seals (Egyptian Museum, Torino)

The Cylinder was originally simply rolled by the palm of the hand over the surface of the clay to be stamped. The cylinder seal disappeared, but a relict of this primitive method survived in the pictures of Egyptian hieroglyphic system. As explained by Hall (1913), it survived in the sign of the word shen, to "repeat," to "circle round" (to "come full circle"). The idea of this word is to "roll over and over again": for this concept the symbol adopted was (b) in the following figure. It simply represents in a diagrammatic form the Seal-cylinder rolling over the flat clay.

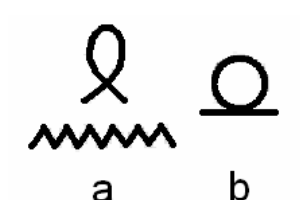

The sign "Shen" evolved from the idea (a) "to repeat" to that (b) of "roll over and over again".

This sign, used to mean an actual seal only, has been found in the inscription on the ivory box-lid of King Ten, for the "golden seal of judgement." 
This is the oldest example of the sign, and it is clear what it was intended to represent ${ }^{8}$. Later on, the origin of the symbol was lost.

Besides being kept in a box, the Cylinder-seal was also worn by its owner with a necklace. The necklace with its seal became the sign of the royal official "who was charged with the custody and use of the royal seal". We have a sign (see figure below, $a, b$ and $c$ ), which shows the ends of the necklace passing through the perforation of the seal (a). The form was altered to (b) and became the usual symbol of the word "to seal". In the form (c), it became the sign of the official keeper of the seal, usually translated as "treasurer."

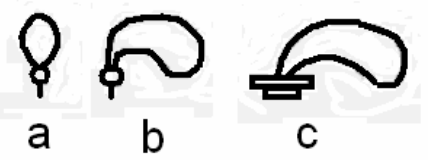

The seal (a) and the keeper of the seal (c).

Under the Old Kingdom, a new form of seal came into use. It was the Buttonseal, usually of ivory or steatite: a circular signet, with a small ring above it for suspension. It was probably introduced into Egypt from the Aegean lands, where it was at that time a usual form of seal.

The place of the Button-seal was soon taken by the Scarab, which, during the Middle Kingdom, was the ordinary form of seal, and later was the usual Sealamulet. It first appeared at the time of the VIth dynasty. There are Scarabs bearing the names of the Pyramid-builders and other kings of the IVth and Vth dynasties, but they are of later manufacture.

\footnotetext{
${ }^{8}$ In ancient Egypt, kings encircled their name with a design called "cartouche". A cartouche is an oval ring that is a hieroglyph representation of a length of rope folded and tied at one end. The term, "cartouche" is a relatively modern one coined by the soldiers of Napoleon's expedition in Egypt. The cartouche, known in ancient Egypt as the Shenu, is derived from the Egyptian verb, Sheni, which means to encircle. It is very similar to the Shen sign, with circular form. In fact the earliest use of the cartouche in which the king's name was written, was circular and identical with that sign.
} 
The Scarabs of the Pyramid-builders are mostly of the Saite period. In this period, the art of the Pyramid-builders was greatly admired and generally imitated. Moreover, the names of great kings of old times were regarded as powerful protective charms, and so were engraved on Scarabs.

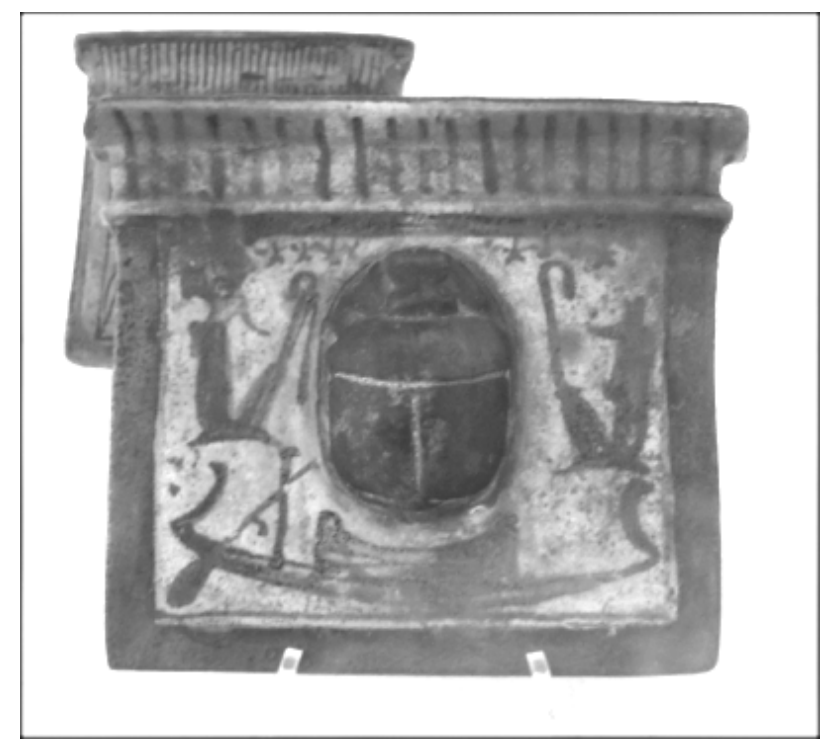

A mummy pectoral in the form of a shrine with a scene of the falcon haded god on a sun bark, recumbent Anubis, Isis and Nephtis and encased scarab (New Kingdon, Late perdiod, Egyptian Museum, Torino).

The Scarab was originally a purely religious object, the emblem of re-birth in the Underworld and of the god of Khepera. He was associated with rebirth, renewal and resurrection. His name means to-come-into-being. When the rival cult of Ra gained significance, Khepera was identified as the aspect of $\mathrm{Ra}$ constituting the dawning sun, the sun when it comes into being every day. Amulets in the form of the Scarab-beetle were buried with the dead, and then were, by a transition, adopted as magical protections for the living, strung upon necklaces, side by side with the small Cylinders and Button-seals that bore the names or devices of the wearer. 
The form of the Scarab necessitated a flat base upon which the insect could stand. This base naturally suggested itself as the field for the engraving of an image or inscription of a seal. Seal devices were so cut upon the originally funerary Scarab amulets. Till the end of the XVIIIth dynasty, Scarab was an amulet and the most usual form of seal.

The most ancient Scarabs known are purely amulets, and have no mark of a seal role on them. These blue glazed steatite Scarabs has a rude form and geometrical signs upon their bases. They occurred contemporaneously with the Button-seals. The manufacture of fine Scarab-seals does not begin till the XIth dynasty ${ }^{9}$.

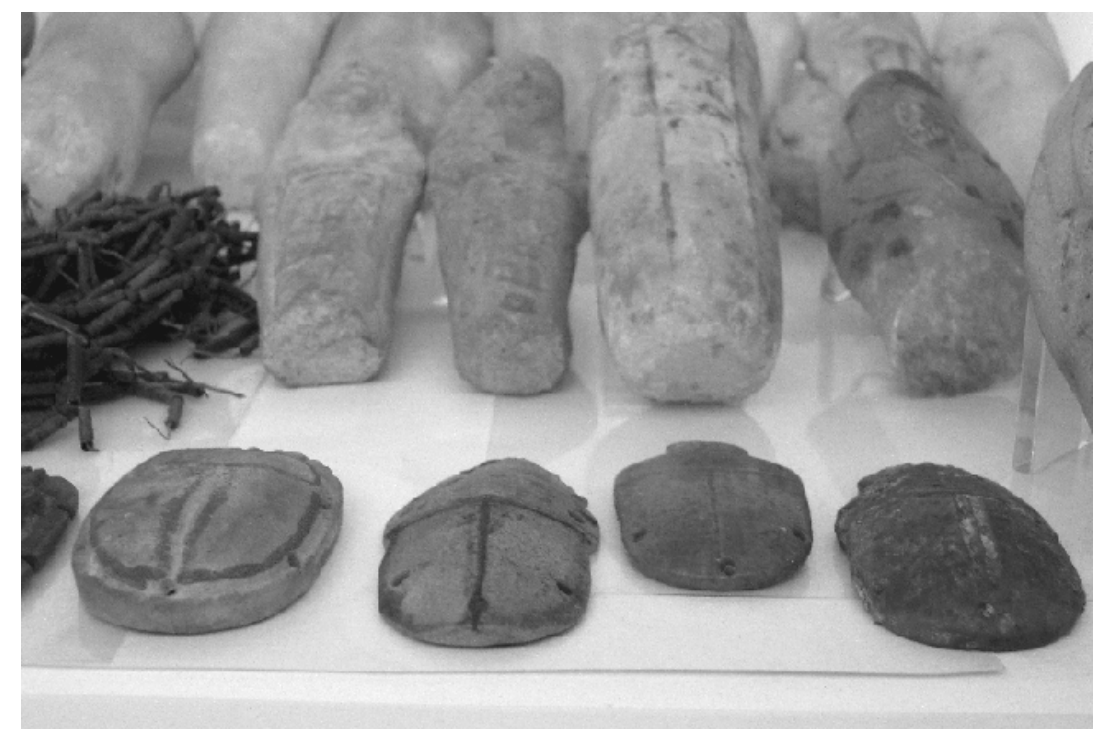

Blue glazed Scarabs in front of group of shawabtis

(Egyptian Museum, Torino).

The Scarab-seals that bore the royal name were not necessarily property of the king or his treasures, nor did they possess any official character. The royal name was usually inscribed upon the seal as an additional magical protection for the owner of the seal. Many Seal-scarabs were made to be buried with the

${ }^{9}$ W. M. Flinders Petrie, 1917 
dead, continuing then the original function Scarab-amulet, and are the seals of the dead man uses in the Under-World. The name of the person was inscribed upon the Scarab. The sign meaning "deceased" was added on many of these Scarabs.

A new style of decoration introduced into Egypt, about the XIth dynasty, from Crete and the Aegean Islands, produced Scarabs with inscriptions often surrounded by a border of spiral volutes. There are beautiful spiral designs which occupy the whole base of the Scarab, without any inscription. These designs were often combined with flowers.
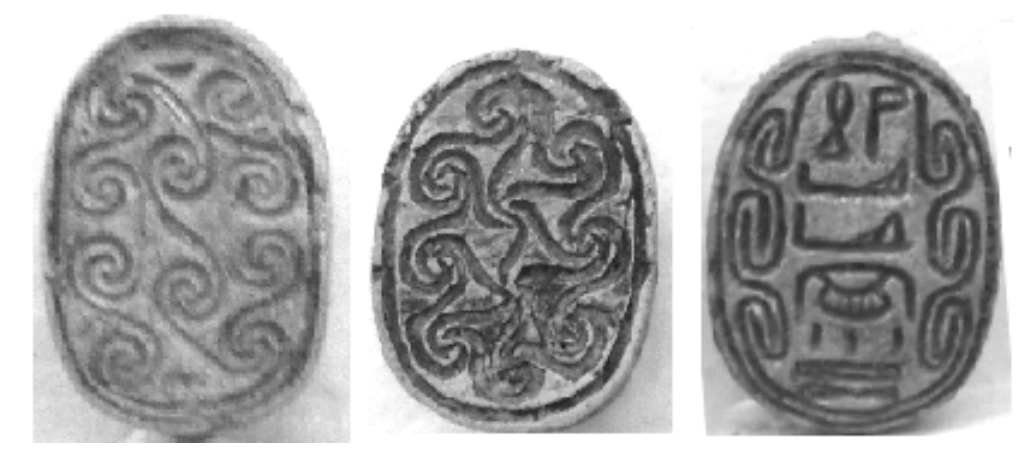

Spiral designs on Scarabs (Egyptian Museum, Torino)

The Scarab was used also as bezel of a gold or electrum finger-ring, hold by means of a twisted spiral wire, which passed through the perforation of the Scarab, and was twisted up on either side round the ring like a spring. Under the Middle Kingdom, the Scarab was usually not mounted but simply worn as a jewel with a string or chain, like a Cylinder or a Button-seal.

For what concerns the Heart-scarabs, in accordance with the prescriptions of the Book of the Dead, they are usually made of green stone. The Heart amulets became popular in the New Kingdom, at the same time as the Book of the Dead. It was placed on the upper torso of nearly all mummies. Some amulets are shaped like a bull's heart. Others have the Scarab shape. Very often they 
are given human heads, or rather faces, rudely and flatly cut. This human face is very characteristic of the Heart-scarabs of the later Middle Kingdom.

Towards the end of the Middle Kingdom, Cowroids, Plaques and other Scaraboid forms appeared. Their popularity extended greatly, the Cowroid being especially popular during the Hyksos Period, and the Plaque at the beginning of the XVIIIth dynasty.

During their history, the Egyptian seals oscillated between a role of seals and their features of amulets. For instance, the Plaque was actually a seal, without any amuletic character then, but, when it was bearing the name of a king or a god, it is was an amulet too. In the time of the XVIIIth dynasty, all seals, Cylinder seals included, became amulets.

Under the Middle Kingdom, the Scarab was an amulet and also a seal, whether of the living or the dead. Under the XVIIIth dynasty, we find the Scarab reverting to its original position as an amulet only. Used as amulets by the common people, these Scarabs have inscribed the name of the king in various combinations. And in fact it is possible to find many Scarabs bearing the name of Thothmes III, who had a very long reign.

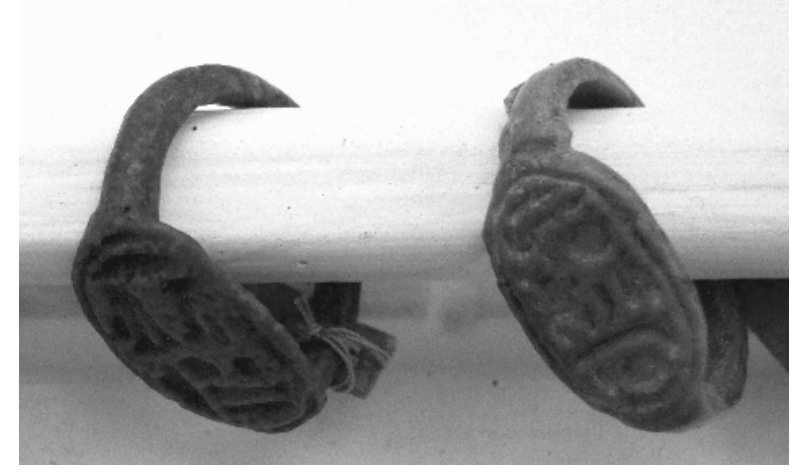

Solid Signet-rings (Egyptian Museum, Torino)

Towards the end of the XVIIlth dynasty another fact restricted the use of Scarabs as seals. It was the invention of the solid Signet-ring. The sealinscription or design was transferred from the movable bezel to the body of the 
ring itself. The bezel was obtained by expanding the ring into a flat oval, where the signet was placed.

Under the XIXth dynasty no development of any interest can be pointed out in the history of the Egyptian seal. After the end of the XXVIth dynasty the Sealscarab suddenly ceased to be made at all in Egypt. As a movable seal bezel, only the stone Plaque survived; and during the Ptolemaic and Roman Periods the most usual seal was the signet-ring, generally of the ordinary classical types.

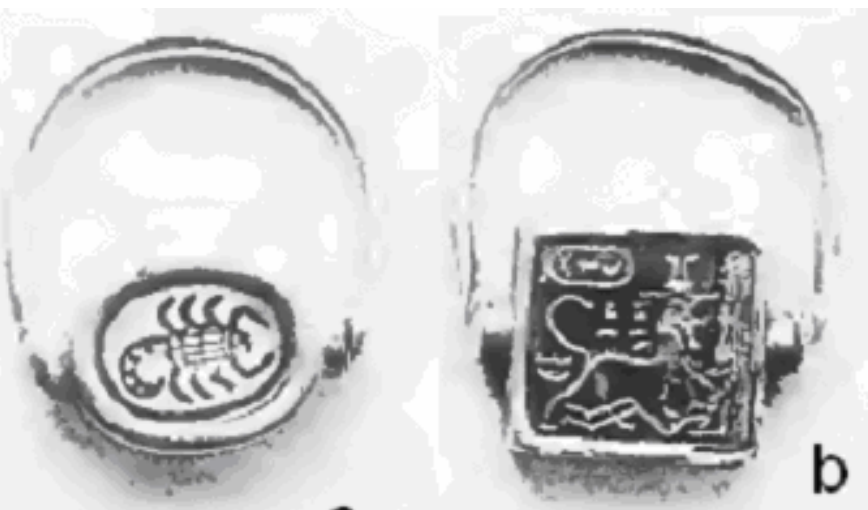

a

Glazed steatite Scarab, in gold mount, XVIIIth Dynasty (a) and a plaque of Thothmes III, XVIIIth Dynasty (b).

\section{RELIGIOUS BACKGROUND.}

The Scarab was one of the most ancient religious emblems of Egypt. The beetle was the emblem of the creating Sun-god, Khepera, originally a deity distinct from $\mathrm{Ra}$, the Sun-god of Heliopolis. Probably this god was worshipped by an old solar cult of the Nilotes, distinct from the Ra-worship.

The peculiar habits of the Scarabaeus caught the attention of the ancestors of Ancient Egyptians. This insect rolling along his great ball of dung seemed to explain how the Ball of the Sun was rolled across the sky. The power that moves the sun in the sky was thus imagined as Scarab, an aspect of the god called Khepera. 


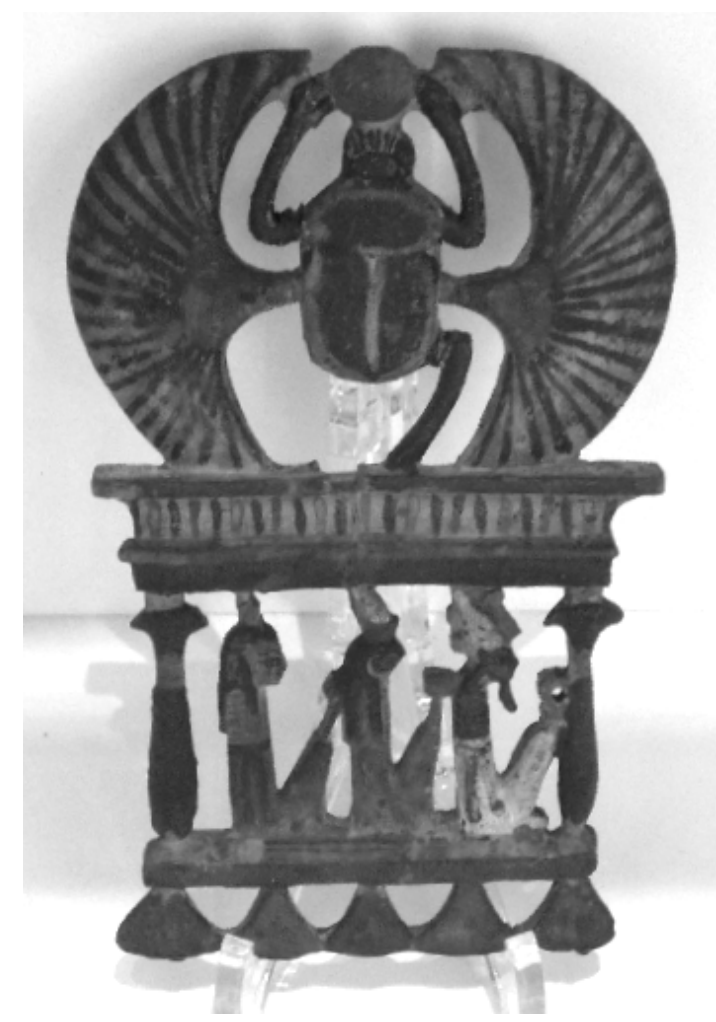

A widged-scarab holding the sun disk between his legs

(Egyptian Museum, Torino)

A wonder is connected with the little insect. The ancient Nilotes observed the small new born Scarabs come out of the ball of dung. As the difference between male and female beetles was not evident, all of them seemed to move a dung-ball. As a conclusion from the fact that small Scarabs were coming out of the ball, the Egyptian assumed that Scarabs were male only and that they created their new generations from the ball they had made.

The idea that Khepera was self-created so permeated the mind of Egyptians that the Scarab became the starting centre of new religious conceptions. The idea of a personal resurrection started to be associated with the Scarab, a resurrection that for Egyptians was to a new life in the Under-world. They hoped that this resurrection was assured to the dead man, by placing over his heart of a stone image of the Scarab. The Scarab turned into the emblem of life renewing itself unaided forever. 


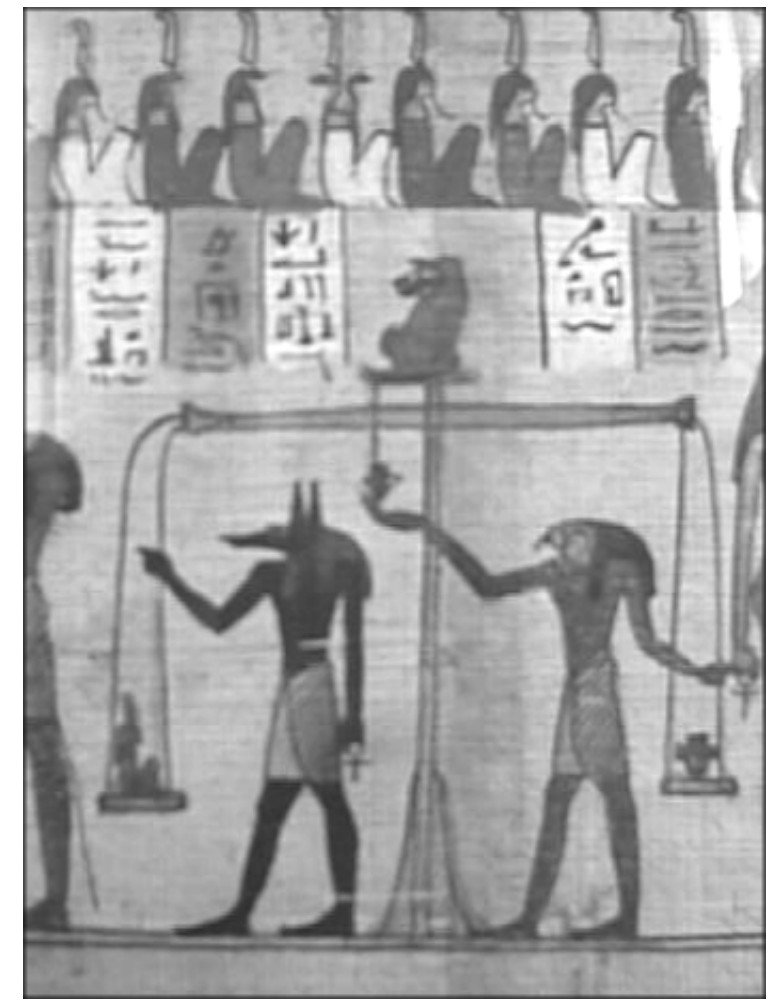

The Weighing of his Heart in the "Hall of Double Truth"

(Egyptian Museum, Torino)

With the help of the Scarab over his heart, the dead man might find good judgement in the "Hall of Double Truth". He might hope in a satisfactory result of the Weighing of his Heart. In the latter days of Egypt, the hope of just judgement and then of a renewed life in the Underworld become confused with a foreign idea of renewed life upon this earth.

Since it was a seal as well as an amulet, the Scarab became identified with various superstitions. The inscriptions upon many Scarabs are testimonies of superstitions perturbing the minds of Egyptians. The small Scarab turned into an amulet which would protect the owner against all kinds of harm in this life, as well as the next. 


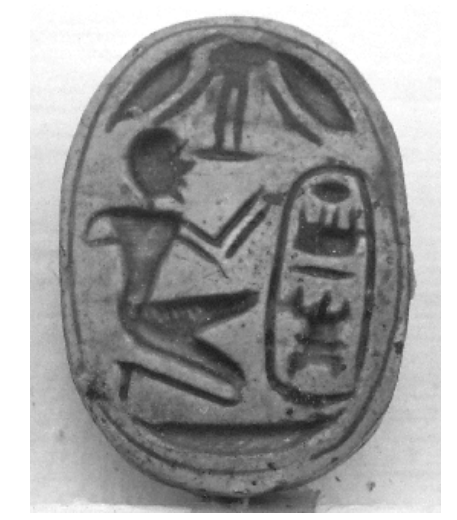

Kneeling man under a winged-sun (Egyptian Museum, Torino).
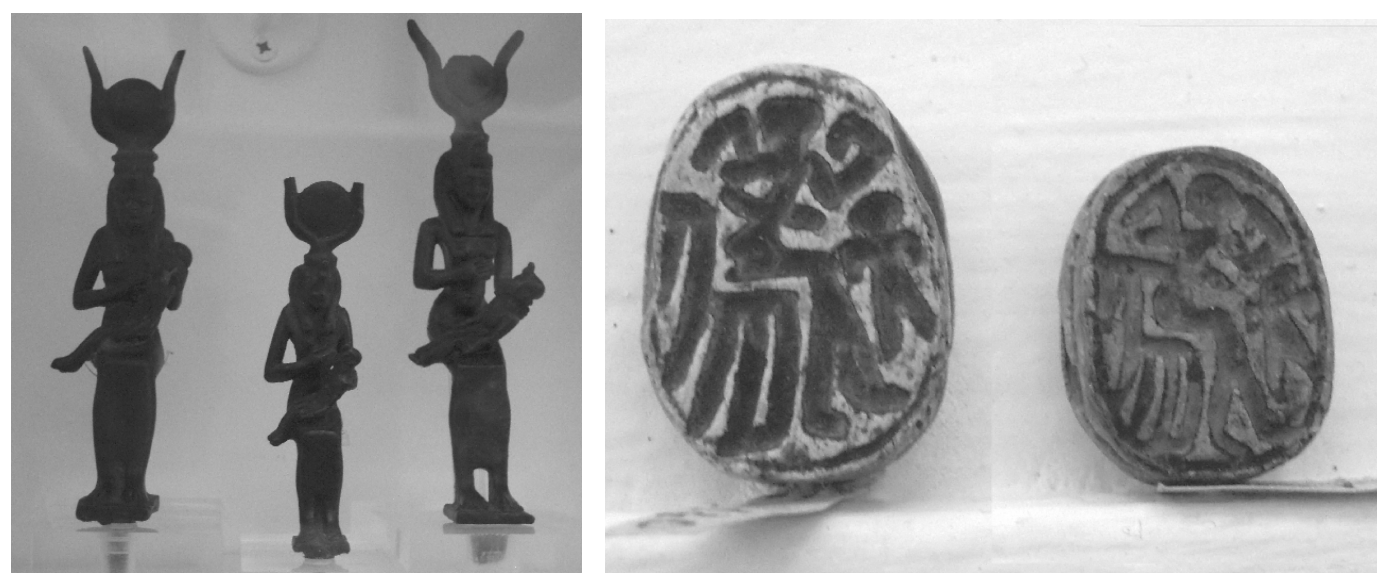

Small statues of Isis and Harpokrates and Scarabs

If inscribed suitably, the Scarab and the gods invoked on him were blessing the owner. Amon and Ptah are most invoked upon the Scarabs, but the names of Bast, Khensu, Mut, Buto, Isis and Harpokrates appear. The latter couple was preferred to be shown as the Mother-goddess with her child, than by their written names. On the small Scarabs, the name of Osiris, the god of the dead, appears rarely: this is significant of the fact that the ordinary small Seal-scarabs were designed for the protection of the living, not of the dead. Osiris appears upon the great Heart-scarabs that were intended for the dead only.

As prescribed in the Book of the Dead, a Heart-scarab of basalt or green stone was placed at the heart of a man, on the breast of the mummy, after the 
ceremony of the "Opening of the Mouth". On the base, this Heart-scarab was inscribed with the necessary Chapter of the Book of the Dead.

\section{HISTORICAL IMPORTANCE OF SCARABS.}

Another interest for Scarabs is its relation to Egyptian history. Of all magical protections against evil, one of the most potent was the name of the reigning King. Therefore the royal name appears so commonly upon Scarabs. The name of the king, who was reigning at the time they were made, was placed upon Scarabs merely as an amulet, just as the names of gods were placed upon them. The names could also be those of deceased kings (Menkaura, Thothmes III, Amenhetep III) who long after their deaths had attained the rank of demigods in the popular religion.

The inscribing of royal names upon Scarabs is of importance when they are the only evidence for the existence of a king. This kind of evidence from Scarabs is the only available knowledge of many monarchs of the Hyksos Period. For many of those kings, the only record of their existence is the inscription of their names upon Scarabs.

The evidence of inscription on Scarab must be used with caution for Scarabs of the Saïte Period (XXVIth dynasty), because in that period the Scarab-makers had a habit to inscribe also names of purely imaginary kings. It seems improbable that this practice were common at the time of the Hyksos, and then it is possible to guess that the regal names upon Scarabs of the Hyksos Period are really those of actual monarchs ${ }^{10}$.

In the reign of Amenhetep III, a number of large Scarabs were made on which were inscribed records of the king's reign and that of his great queen, Tii. Tjere is the king slaying lions in Mesopotamia and hunting of wild cattle in Egypt. Among scarabs there are also truly "historical" objects, which are large, being of the same size as the Heart-scarabs. They were issued according to a royal order for commemoration of important fact, exactly as we have commemorative medals and coins.

${ }^{10}$ K.H. Hall, 1913 

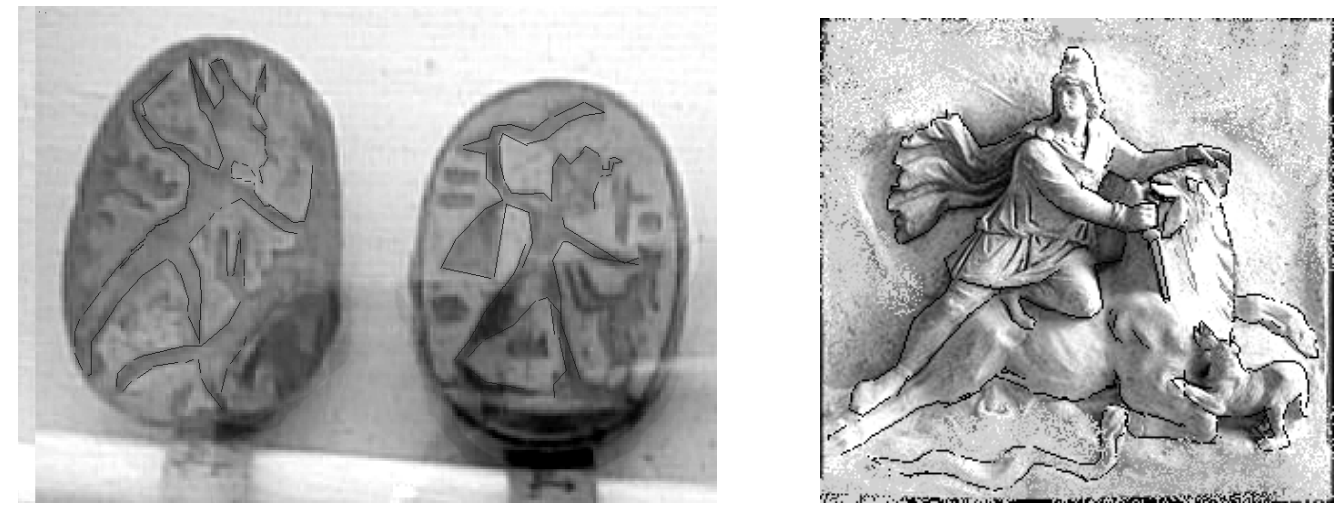

On the left, two scarabs with a king slaying a lion (Egyptian Museum, Torino) On the right a bas-relief showing Mithras slaying the bull. Note how the Egyptian artists were able to represent a complex scene in a very small ovoid space, $3 \mathrm{~cm}$ height.

According to Hall (1913), we can obtain hints of historic events even from the little Amulet-scarabs, when it is possible to discern the symbolism of the pictures and ideographs. In the conflict between a lion and a crocodile upon the Hyksos Scarabs, there is represented the struggle between the desert-kings and the native Egyptian princes of the XIIIth dynasty, who worshipped the crocodile-headed Sebek.

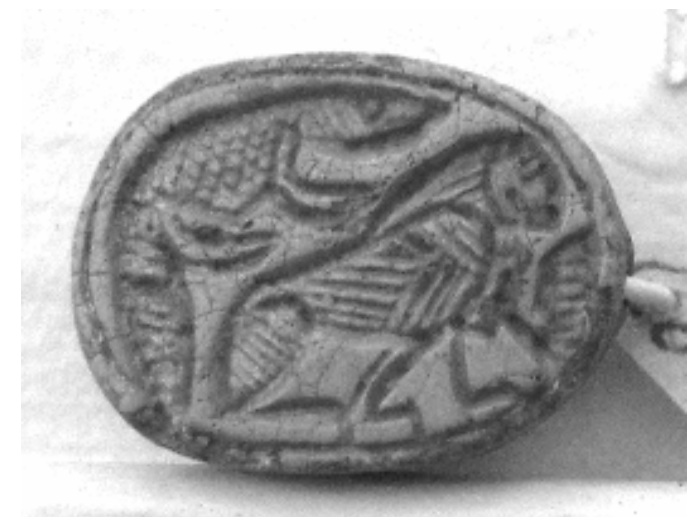

A lion and a crocodile on a scarab seal

(Egyptian Museum, Torino) 
The importance of Scarabs for the dating of objects with which they are found can also be considered but the evidence of Scarabs for this purpose must always be used with caution. In fact, there is always the possibility that the Scarab is much older than the objects with which it is found, having been preserved as an amulet for some time previously.

\section{ARTS IN SCARABS.}

Before considering the artistic value of a Scarab, let us note that its manufacture was typically Egyptian and that the glazed steatite and faience, of which Scarabs were usually made, were the most characteristic of Egyptian materials. In the Egyptian art, Scarabs hold the same place as coins and gems hold in Greece. As gems and coins are microcosms of Greek art, so the Scarabs are microcosms of macroscopic Egyptian art. We see scenes of kings fighting with enemies, in pursuit of lions or running with chariots. These are miniatures of sculptured scenes on the temple walls.

We have also Scarabs with rough pictures and hieroglyphs. The majority of Scarabs are neither very good nor very bad, due to the fact that they were cut in the soft steatite. Fine Scarabs of hard stone are rare objects. Those, survived to the injuries of time and men, are beautiful products of Egyptian art.

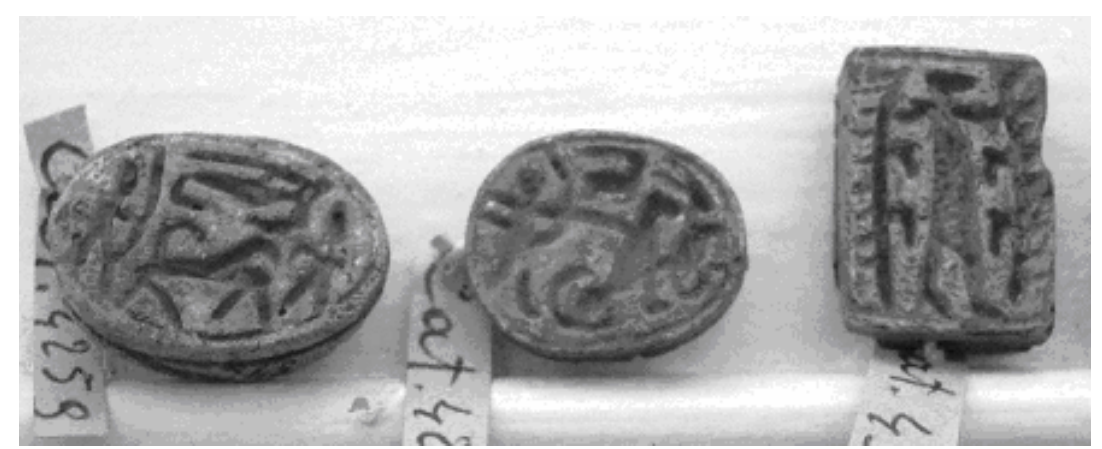

Hunting on Scarabs (Egyptian Museum, Torino) 


\section{ICONS ON SEALS}

Images on seals are of several types, often accompanying inscriptions with names of kings and gods, and with specific meanings. We can consider then the Egyptian scarab as carrying icons, not simply images.

On scarabs, we see human figures, animals, flowers or specific symbols. Coils and entanglements of cords are characteristic of the Middle Kingdom Period. Among images of animals, goats and antelopes had a great success during the Hyksos period, because Hyksos took the antelope form of the Egyptian god Seth to represent their own deity ${ }^{11}$. In the case of Egyptian scarabs, books reporting the collections are available, and therefore it is possible to create a sort of statistics of the used images. We find also a relevant number of stamp seals with dots, cords and coils, in highly symmetric patterns.

Because the scarab has also an amuletic function, let us consider the subdivision by W.M. Flinders Petrie ${ }^{12}$, of amulets in specific classes. We have amulets with the shape of living creatures or of their parts, for instance with the shape of an eye or ear, to assure the death the possibility of seeing and hearing. Then we have the objects with those particular shapes, believed to possess special magic powers. A class is devoted for protection against misfortune, illness and calamities. Another class of amulets is devoted to guarantee the ownership of goods for life in the Under-world. At last, we find those amulets, in the shape of gods, also in their zoomorphic representations. In fact, we could arrange the scarab seals in classes according to their amuletic function. Many scarabs have images of animals, which have a specific meaning for protection. Fishes are symbols of regeneration. Sometimes they have a lotus bad in their mouth. Lotus is another symbol of regeneration and resurrection. The fish is also a protection against drowning.

To wear a scarab with the image of a scorpion is a protection against these animals. The same, in the case of crocodiles.

\footnotetext{
${ }^{11}$ F. Magnarini, 2004

${ }^{12}$ W.M. Flinders Petrie, 1994
} 
Who has a scarab with an antelope or gazelle absorb its strength, agility and velocity, then he can become a good hunter. In the Hyksos period, the antelope was a representation of Seth.

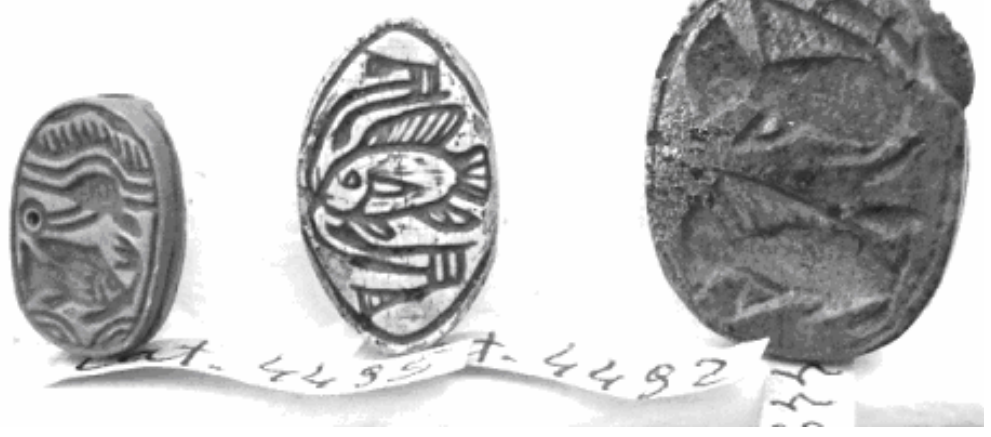

Fishes on scarabs. The Horus' Eye (left) was a strong defence against the evil and a sign for protection (Egyptian Museum, Torino)

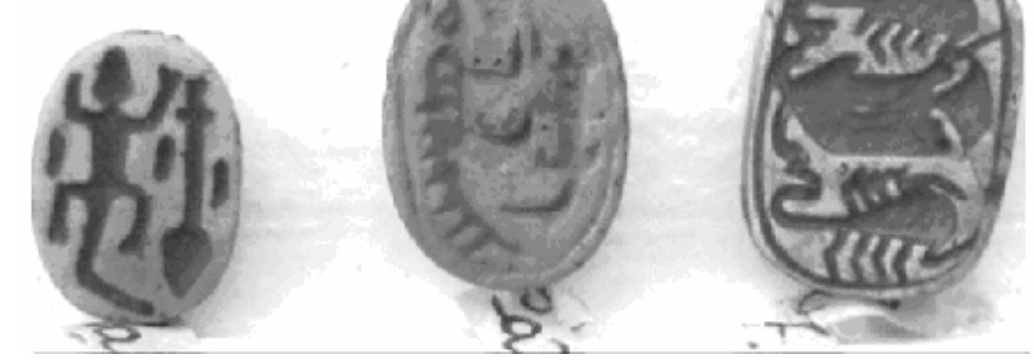

Lizards, crocodiles and scorpions are also displayed on scarabs.

They were a protection against dangerous animals.

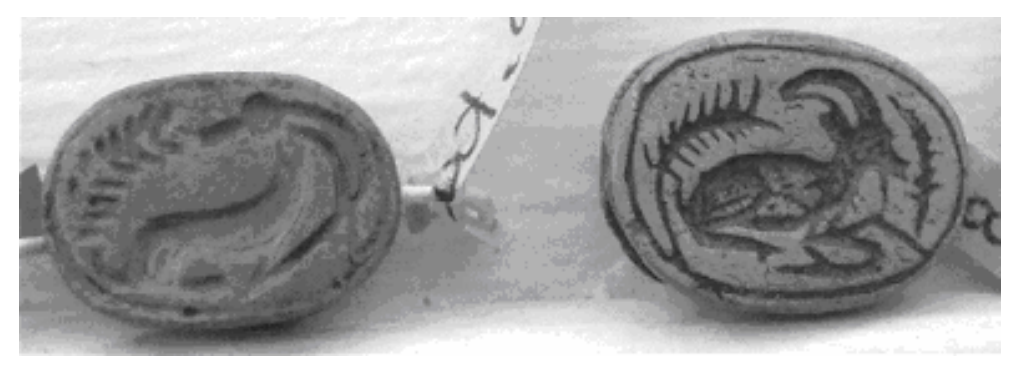

To wear a scarab with an antelope helps you to become a good hunter. In the Hyksos period, the antelope was a representation of Seth. 


\section{THE "DJED"}

According to Flinders Petrie, for the ancient Egyptian there were objects with particular shapes, believed to possess special magic powers. The Djed is one of these objects. Djed symbol is a pillar-like ancient Egyptian symbol representing stability. It has been interpreted as the backbone of the Egyptian god Osiris. Djedu is the Egyptian name for Busiris, a centre of the cult of Osiris. During the Renewal Festival, the djed would be ceremonially raised as a phallic symbol symbolising the "potency and duration of the pharaoh's rule". In their 2004 book, The Quick and the Dead, Andrew H. Gordon and Calvin W. Schwabe speculated that the Ankh and Djed symbols have a biological basis derived from ancient cattle culture, thus the Ankh - symbol of life - thoracic vertebrae of a bull (seen in cross section) and the Djed - symbol of stability base or sacrum of a bull's spine.

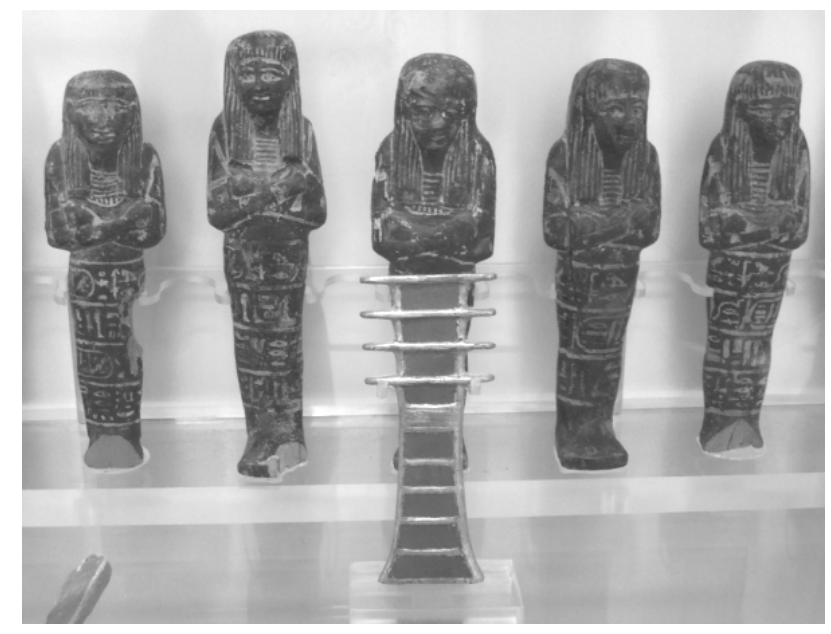

Golden Djed in front of group of shawabtis (Egyptian Museum, Torino).

A Djed column is often painted on the bottom of coffins, where the backbone of the deceased would lay; this identified the person with the king of the underworld, Osiris. It also acts as a sign of stability for the deceased' journey into the afterlife. 

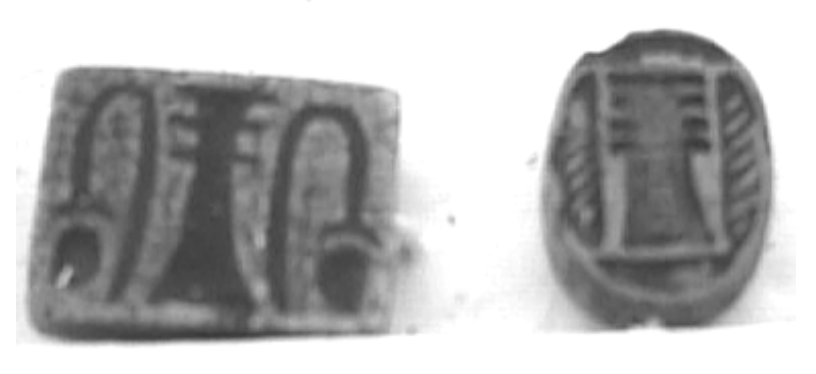

A plaque and a button seal. Note the different symmetry of the flowers on the plaque and the feathers on the right (Egyptian Museum, Torino).

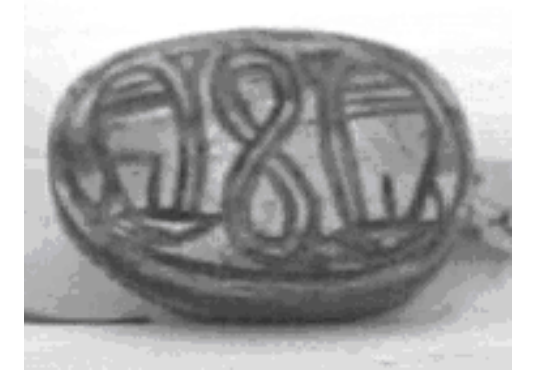

The sign of "infinity", the never-ending, recurrent path (Egyptian Museum, Torino).

\section{THE URAEUS AND THE EYE OF HORUS}

The Uraeus is the stylised, upright form of an Egyptian spitting cobra, used as a symbol of sovereignty, royalty, deity, and divine authority in ancient Egypt. The Uraeus is a symbol for the goddess Wadjet, one of the earliest of Egyptian deities. She became the patroness of the Nile Delta and the protector of all of Lower Egypt, so her image was worn by the kings as a head ornament, as a part of their crown. The king was recognized only by wearing the Uraeus, which conveyed legitimacy to the ruler. There is evidence for this tradition even in the Old Kingdom during the third millennium BC.

The cobra is then an emblem of Lower Egypt, associated with the king and kingdom of Lower Egypt. At the time of the unification of Egypt, the image of Nekhbet, represented as a white vulture, who hold the same position as the patron of Upper Egypt, joined the image of Wadjet on the crown of the 
pharaohs who ruled the unified Egypt. The two goddesses were known as "The Two Ladies", protectors and patrons of the unified Egypt.

It is also associated with the sun and with many deities. The cobra represented the "fiery eye of Ra", in which two Uraei can be seen on either side of a winged solar disk. As the pharaohs were seen as a manifestation of $\mathrm{Ra}$, it was believed that the Uraeus protected them by spitting fire on their enemies from the fiery eye of the goddess. In some mythological works, the eyes of Ra are said to be Uraei.

Wadjets existed long before the rise of this cult when they originated as the eye of Wadjet as cobra and are the name of the symbols also called the Eye of the Moon, Eye of Hathor, the Eye of Horus, and the Eye of Ra, depending upon the dates of the references to the symbols.

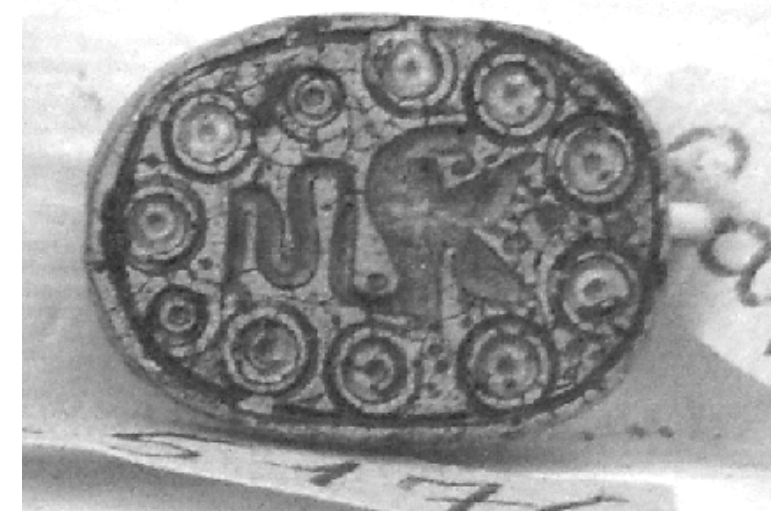

Scarab with Uraeus (Egyptian Museum, Torino)

The Eye of Horus (previously "Wadjet" and the Eye of the Moon and afterwards as The Eye of Ra, or "Udjat") is an ancient Egyptian symbol of protection and royal power from deities, in this case from Horus or Ra. The symbol is seen on images of Horus' mother, Hathor, and on other deities associated with her. In the Egyptian language, the word for this symbol was "Wedjat". It was the eye of one of the earliest of Egyptian deities, Wadjet, who later became associated with Bast, Mut, and Hathor as well. Wedjat was a solar deity and this symbol 
began as her eye, turned into the Eye of Horus. The Wedjat was intended to protect the king in the afterlife and to ward off evil.
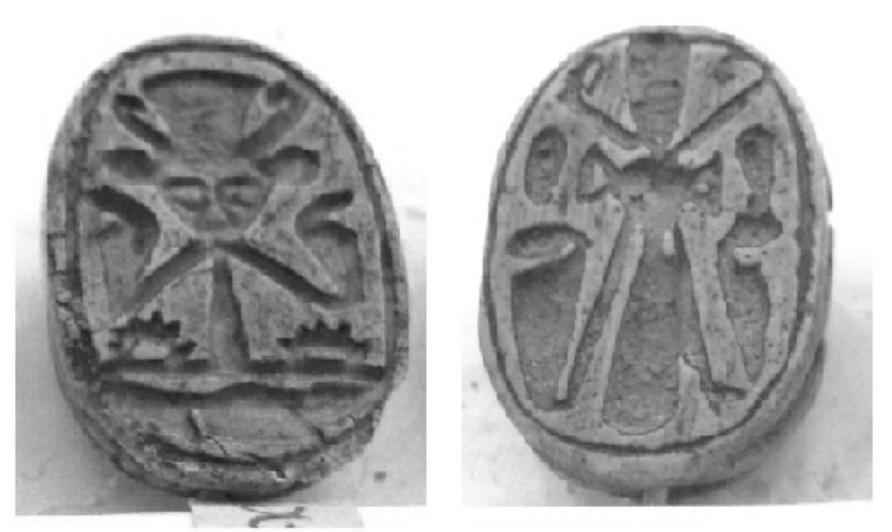

Hathor (Egyptian Museum, Torino)

Horus was an ancient Egyptian sky god in the form of a falcon. The right eye represents a Peregrine Falcon's eye and the markings around it, that includes the "teardrop" marking sometimes found below the eye. As the Wadjet (also Udjat), it also represented the sun, and was associated with Horus' mother, Isis, and with Wadjet another goddess, as well as the sun deity Ra. The mirror image, or left eye, sometimes represented the moon and the god Thoth. The parts of the 'Eye of Horus' were used to represent fractions in the Egyptian mathematics.
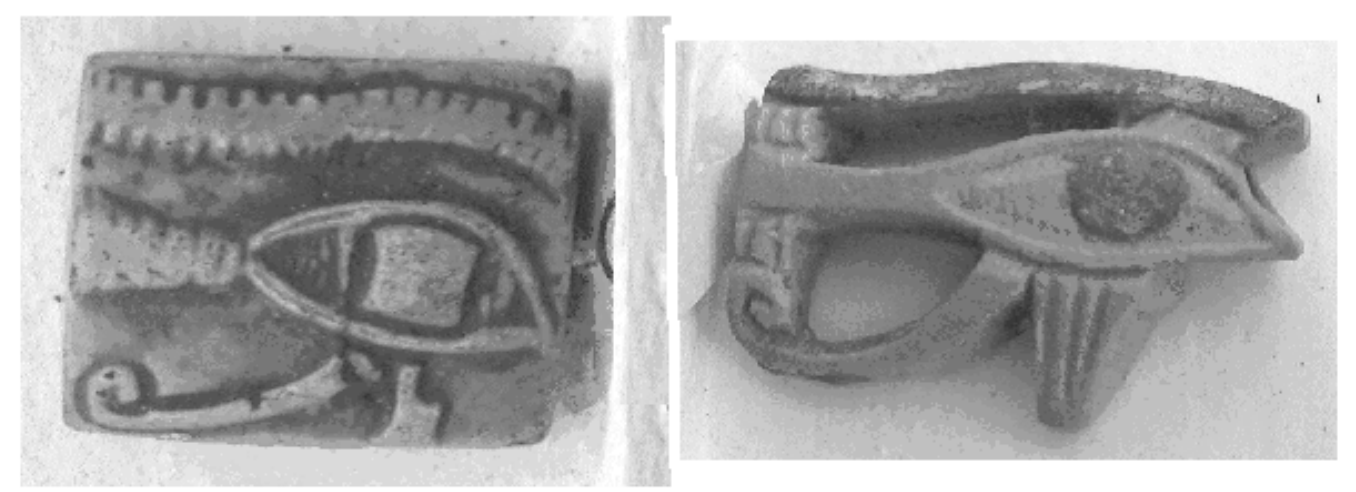

The Udjat is the sound eye of Horus, and symbolizes healing and protection (Egyptian Museum, Torino). 


\section{SPHINXES AND FANTASTIC ANIMALS}

A sphinx is a zoomorphic mythological figure which is depicted as a recumbent lion with a human head. To these very old sculpted figures of Egypt the ancient Greeks applied their own name for an archaic monster of Greek mythology. Similar creatures appear throughout South and South-East Asia.

Usually depicted with a human head, occasionally sphinx is depicted as a lion with the head of a falcon, hawk, or ram. The hieracosphinx, that is the lion with a falcon's head is like a chimera, the mythical beast comprising a lion with the gryphon's aquiline head. The figure had its origin in the Old Kingdom and is associated with the solar deity Sekhmet. The use of heads of other animals atop the lioness body followed the titular deities of the city or region where they were built or which were prominent in the Egyptian pantheon at the time.

The role of sphinxes was as temple guardians, placed in front of royal tombs or religious temples. The largest and most famous is the Great Sphinx of Giza, sited at the Giza Plateau on the west bank of the Nile River.

The names that their builders gave to these statues is not known. Before the time of Alexander the Great, the Greek name, sphinx, was already applied to these statues. The historians and geographers of Greece, writing about Egypt, called them ram-headed sphinxes, criosphinxes, and hierocosphinxes, the falcon-headed ones. In Greek mythology, a sphinx is represented as a monster with a head and breasts of a woman, the body of a lion, the wings of an eagle, and a serpent headed tail.

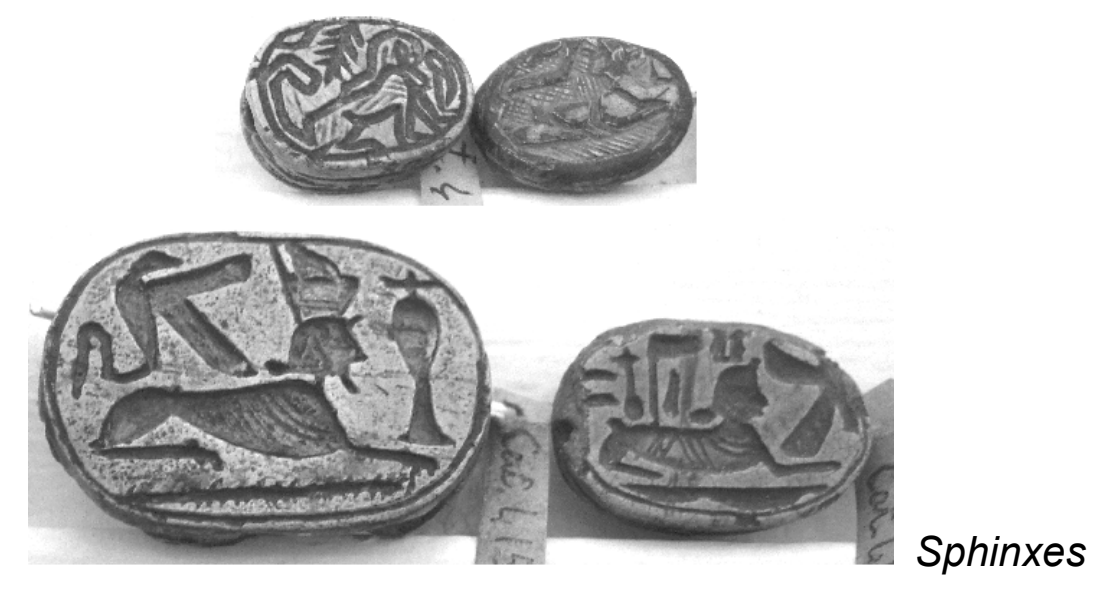



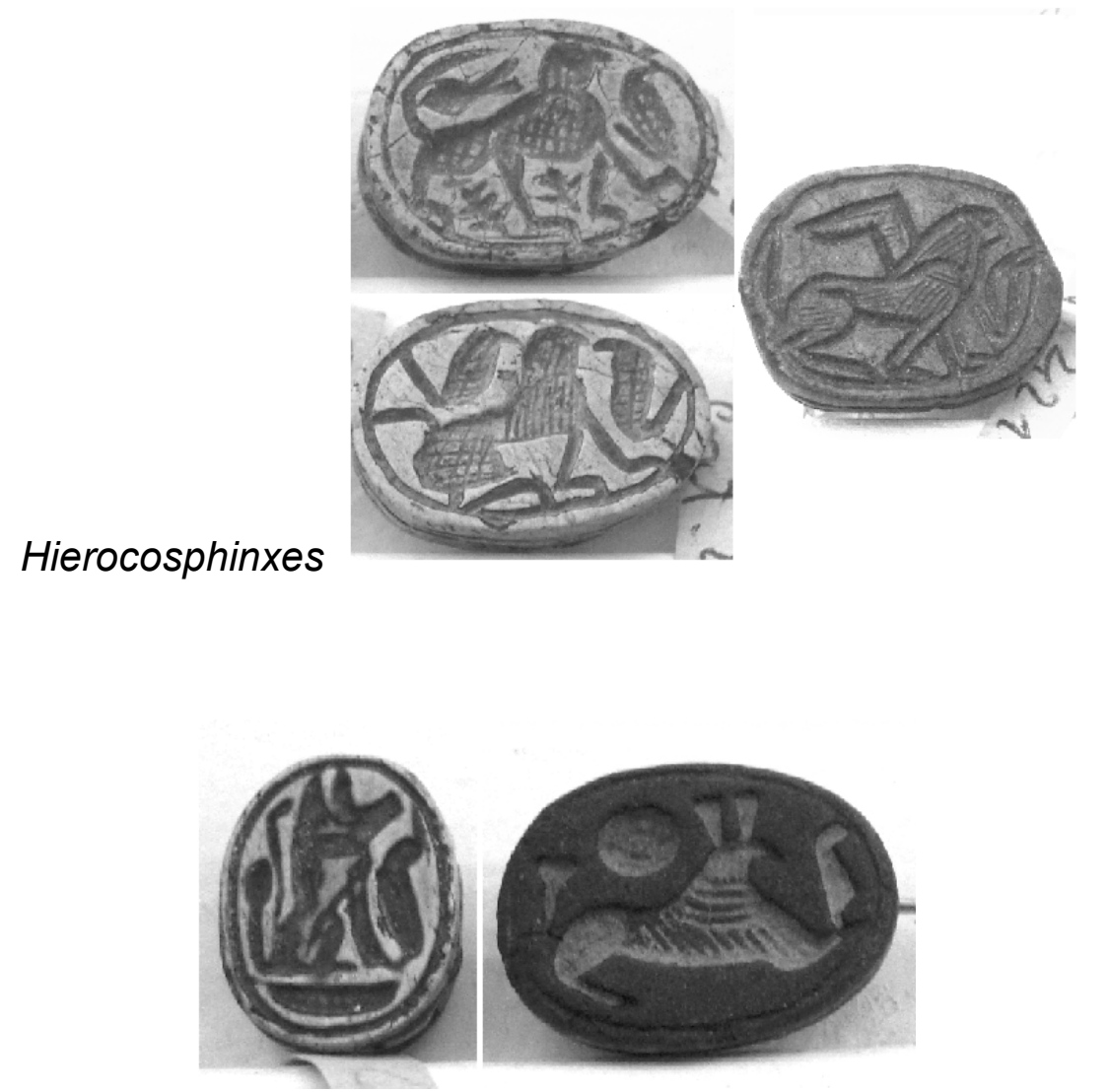

Fantastic animals (Egyptian Museum, Torino)

\section{SCARABS OF THE MIDDLE BRONZE AGE (HYKSOS SCARABS)}

The Hyksos, whose name means "Rulers of Foreign Lands," were an Asiatic people, migrating to Egypt around the XII Dynasty, looking for good land for their herds. Settled in the region of the Eastern Delta, they became powerful and ruled Egypt during XV and XVI Dynasties. The Egyptian Ahmose, founder of the Eighteenth Dynasty, expelled them.

Hyksos scarabs of the Second Intermediate Period in Egypt, 1780-1570 BC (Middle Bronze) appear to imitate the Egyptian ones, but with some changes. Their designs may incorporate kneeling men smelling a lotus flower, characteristic of the early Hyksos period, interlacing and floral motifs, animals motifs and geometric designs ${ }^{13}$.

13 D. Ben-Tor, 1989 


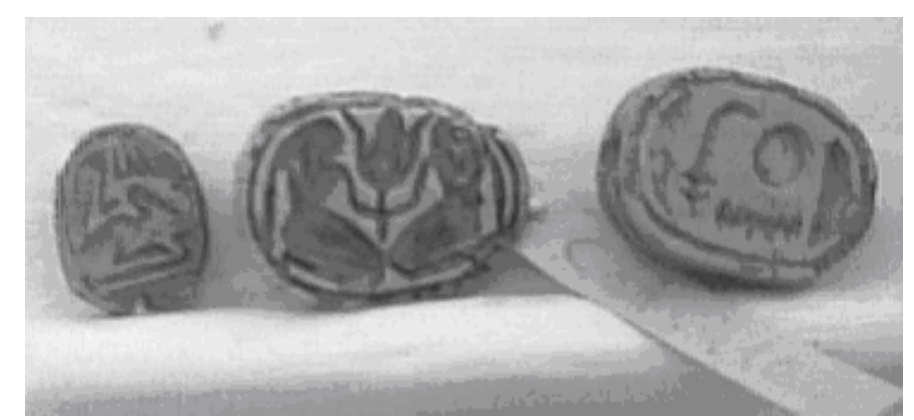

In the middle, a lotus flower between men (Egyptian Museum, Torino).

Among them we find describes four main elements of the geometric designs: (1) Spiral scrolls as a design covering the entire base and as a frame. Some of the scrolls are interlocking, while others are single; S-shaped, C-shaped and round or elongated scrolls are found. This design appears in a vast number of variations and was in use throughout the entire period under discussion.

(2) Concentric circles, usually covering the entire base, but also used in conjunction with other designs or as a frame. Frequently they are linked by lines to a cross pattern, or combined with the spiral scroll motif.

(3) Coiled cord patterns, usually covering the entire base, but sometimes in combination with other elements. In some cases, the pattern is cut and used as a border for a cross pattern or some other cut coiled cord design placed in the centre.

(4) Cross patterns, consisting of spiral scrolls, concentric circles, floral motifs or coiled cord patterns, covering the entire base.

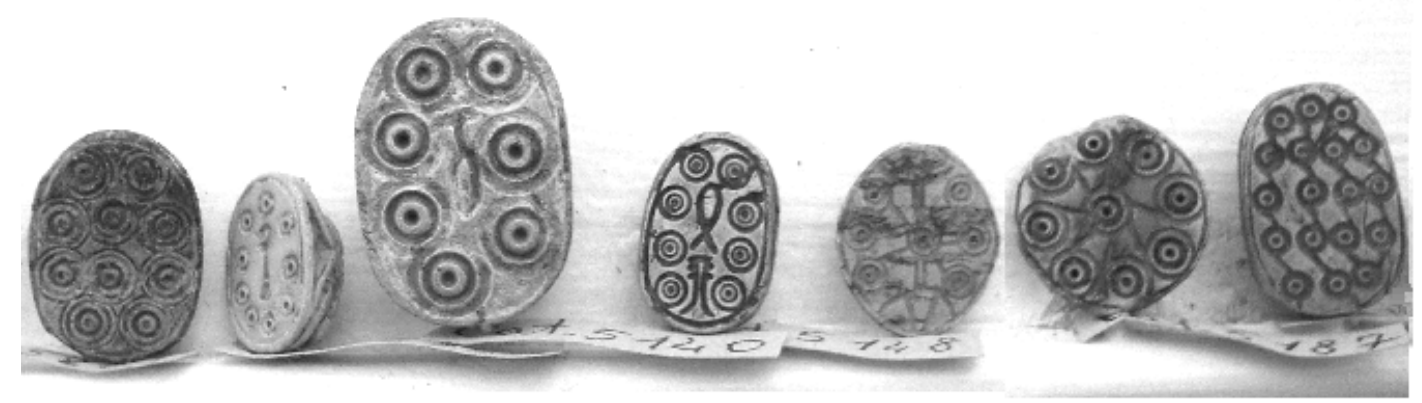

Concentric circles, sometimes attached by lines to central concentric circle, or disconnected are 'good luck' scarabs (Egyptian Museum, Torino). 


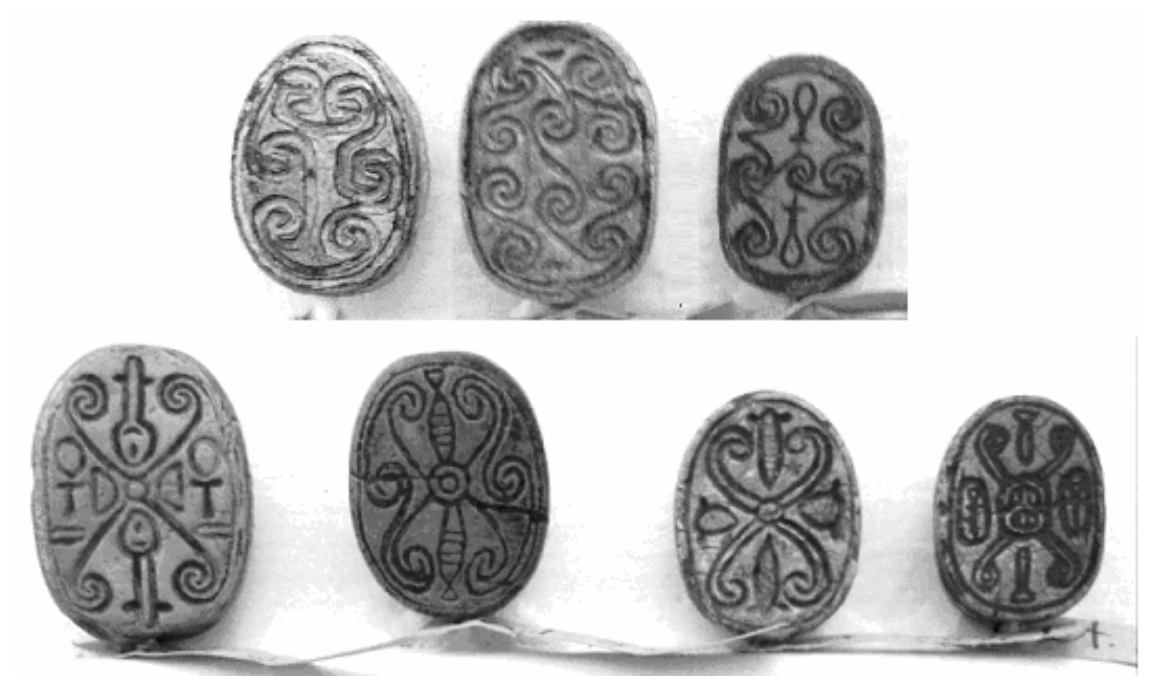

Spirals and cross patterns on scarabs (Egyptian Museum, Torino).

Dating the scarabs is very difficult, because they were passing through many generations. The context in which they have been found does not necessarily indicate the precise age. It is also impossible to date them using the design, because designs were in use for long periods of time, with slightly changes in styles. And so we can find motifs, designated as "Hyksos", on later scarabs of XIX Dynasty. Some of the designs of Hyksos Scarabs, especially scrolls and floral devices, continue all the way through to the XXVI Dynasty. In fact, the Hyksos had a significant impact of the on the whole history of seals.

\section{SYMMETRIES ON SEALS}

A relevant number of Scarab and plaque seals have images which are highly symmetric, mainly with bilateral symmetry, sometimes with two-fold rotational symmetry. It is probable that the symmetry of images was used to increase the amuletic property of the seal.

The mirror symmetry, or bilateral symmetry, is occurring when the two halves of a whole are each other's mirror images. A way to think about this symmetry is to fold the image in the middle, and check if the two halves are identical. In this case, the image has two halves that are each other's mirror image. Rotational symmetry is symmetry with respect to rotations in the space. In the case of an 
image, it has a rotational symmetry, when we observe that it is invariant for rotation about an axis perpendicular to its plane. We find a two-fold symmetry if we rotate the image of 180 degrees, a four-fold one when the rotation is of 90 degrees. Generally, we have $n$-fold rotation when angle is $2 \pi / n$.

\section{ROTATIONAL SYMMETRY}

In many cases, the presence of symmetry in an image turns out to be associated with an idea of beauty, strength and order. Nevertheless, an excessive symmetry can be boring and constraining the creative action. A perfect bilateral symmetry for instance, gives to the observed object a highly static position (an example from an Egyptian bas-relief is shown below). In images or statues, a too fixed appearance can be avoided by a slight breaking of symmetry ${ }^{14}$.

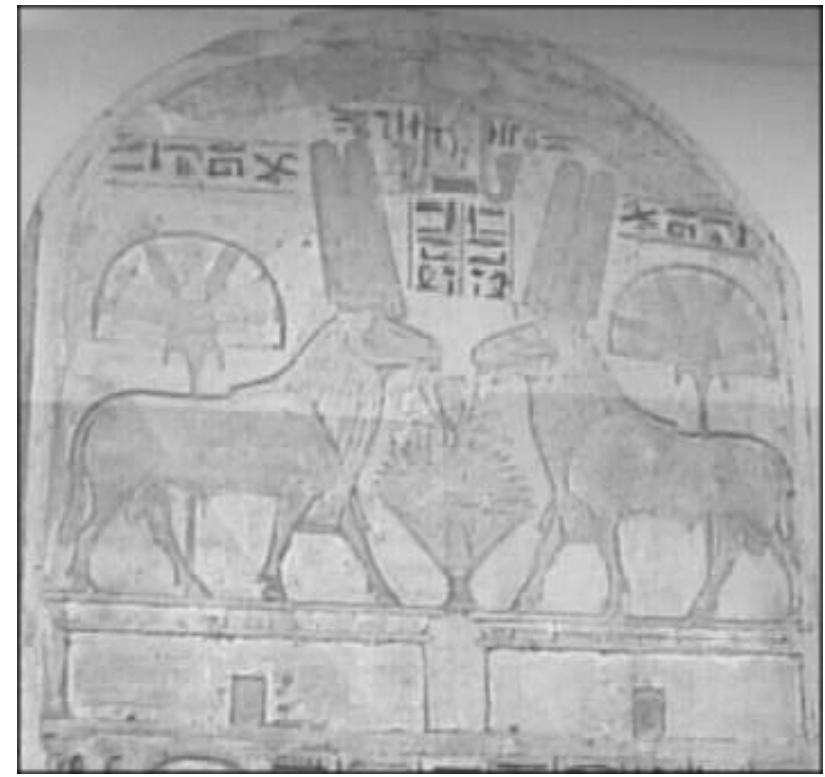

Upper part of a bas-relief, representing god Amon as a double-ram (Egyptian Museum, Torino). Note the perfect bilateral symmetry, so important in art and architecture of ancient Egypt.

\footnotetext{
${ }^{14} \mathrm{~A}$ discussion on symmetry and symmetry breaking in physics can be found in the Stanford Encyclopaedia of Philosophy, at http://plato.stanford.edu/entries/symmetry-breaking/
} 
The rotational symmetry is different, as it is quite natural to follow the image in its rotation in the space. This symmetry produces a feeling of motion and evolution. The use of antisymmetry or of a breaking of symmetry in this case, enhances the idea of inter-penetration or contrast.

Let us consider for instance a well-know symbol, the Yin-Yang symbol of Taoism. As in many religious symbols, the symmetry (or antisymmetry) is used to convey an intuitive meaning. And in fact, we see that the ancient Taijitu image of Taoism has a fascinating use of antisymmetry for rotation about the central point (a two-fold one). In this case the antisymmetry is a rotational symmetry combined with black-and-white inversion of colours. The image actually intends to be a representation of the complementary need for male and female concepts. The rotational antisymmetry catches our attention with a feeling of development in the frame of complementary actions, not of mere recurrence.

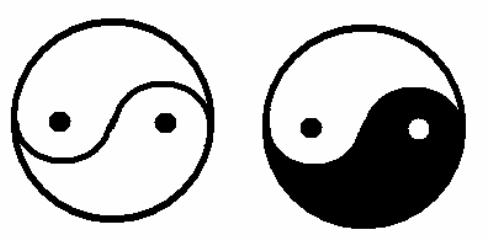

The two-fold rotation symmetry on the left gives an idea of recurrence. The rotational antisymmetry is displayed by the Yin-Yang symbol (on the right).

How old is the rotational symmetry in images? It is very old. We find this symmetry in some stamp seals from Çatalhöyük (7500-5700 BCE), which was a very large Neolithic and Chalcolithic settlement in southern Anatolia. Images on these seals have geometric patterns with bilateral and rotational symmetries.

The impressing of carved stones into clay to seal containers had a long tradition in Near East, in particular in Mesopotamia, with the earliest evidence found in Syria dating to the seventh millennium BCE. During the Ubaid period, 
the variety of designs carved on seals expanded from the simple geometric forms to include animals with humans, snakes and birds. Seals decorated with four-legged horned animals can be easily found. In a very old stamp seal from the region North Syria//raq//ran ${ }^{15}$, dated 5th-4th millennium BC, we see a standing male figure between two horned quadrupeds back to back and head to end. The overall structure of the image is built to respect the two-fold rotational symmetry (see the image below).

On the right side of the same figure, we see a stamp seal from Susa ${ }^{16}$. The seal depicts two goat-antelopes head to tail, inside and outside an oval ${ }^{17}$ [8]. In this seal, the idea of motion is strongly enhanced; the two antelopes seem to run on the rim of the seal.
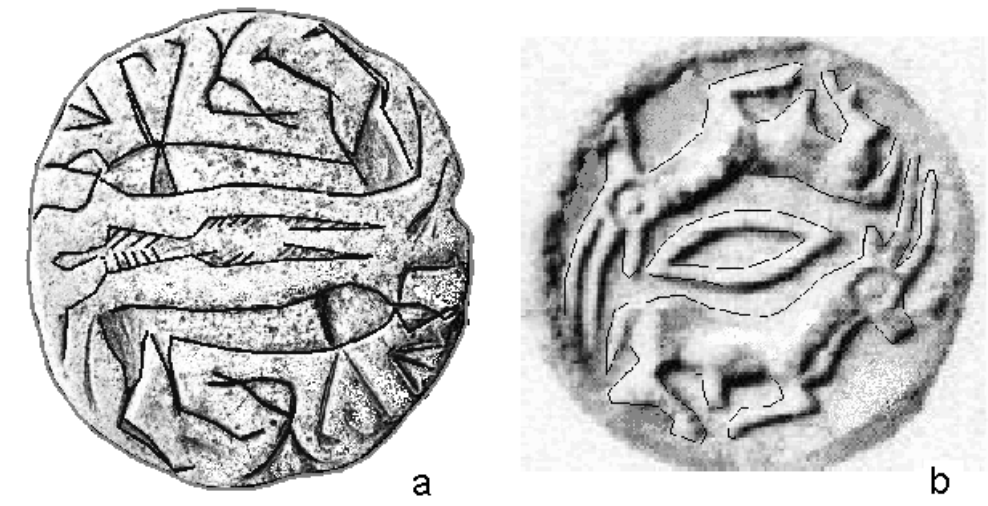

Images on a stamp seal from the region North Syria/Iraq/Iran, dated 5th-4th millennium BC (a), and on a stamp from Susa at Louvre Museum (b).

\footnotetext{
${ }^{15}$ M. Schøyen, Seals, at www.schoyencollection.com/index.html

${ }^{16}$ Susa, in Iran, is one of the oldest known settlements of the world, possibly founded about $4200 \mathrm{BC}$, although the first traces of an inhabited village have been dated to ca. $7000 \mathrm{BC}$.

17 Stamp seals, at

www.hindunet.org/hindu_history/sarasvati/lapis/lapis_lazuli.htm
} 
An evolution of this kind of images is obtained through the breaking of bilateral or rotational symmetrie. The breaking of symmetry can be produced by depicting two animals again, but a predator/prey couple. A late Bronze Age seal from Aegeus with a lion and horned quadruped shows the broken bilateral symmetry in the hunting between two opposite components. This seal can be viewed as an example of antisymmetry: instead of opposite colours, we have antithetic properties of objects depicted on the seal.

And finally, in the frame of a strongly increased creativity, we can admire the miniature of men fighting with bulls, in a beautiful Minoan stamp.

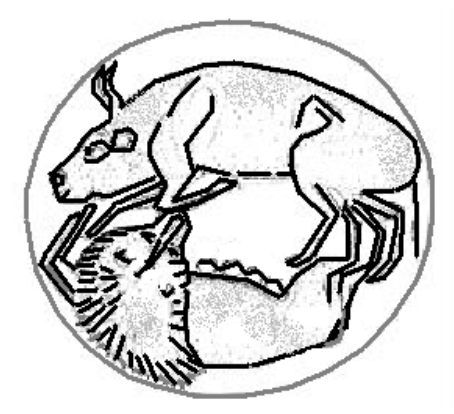

An image from a late bronze age seal from Aegean area ${ }^{18}$

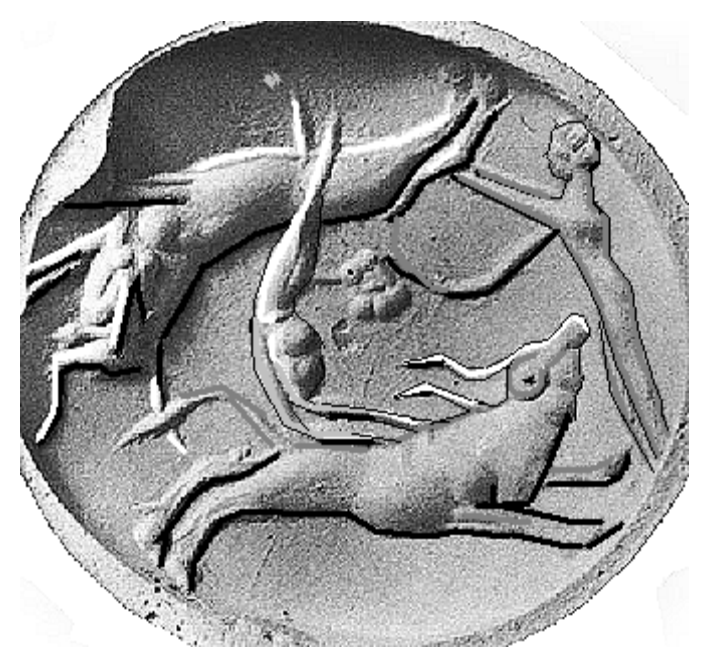

Men fighting with bulls, for Minoan area ${ }^{19}$

\footnotetext{
${ }^{18}$ Late bronze age stamp seal, at

en.wikipedia.org/wiki/lmage:Late_bronze_age_seal.jpg
} 
This seal has four objects, and then in principle it could have a four-fold rotational symmetry: the fact that we have two bulls and two men reduces the symmetry to a two-fold one. Moreover, this symmetry is approximate. Note the impression of movement that this image is able to convey, with bulls careering in full gallop and athletes vaulting on them.

\section{SCARABS AND SYMMETRIES}

To evaluate the presence of two-fold rotational symmetry in images engraved on Egyptian seals, a possibility is to use the catalogues of the huge collections, for instance, of British Museum or Egyptian Museum of Cairo, when of course the direct inspection is not possible (the Egyptian Museum of Torino has a good collection of seals too).

The rotational two-fold symmetry seems to be not so frequent among Egyptian scarab seals, depicting animals. In catalogues, we find few scarabs with two symmetric animals (scorpions, lions, crocodiles or lizards). An exiguous number of scarabs show two different animals. The hunting predator/prey represented is probably from Hyksos period.

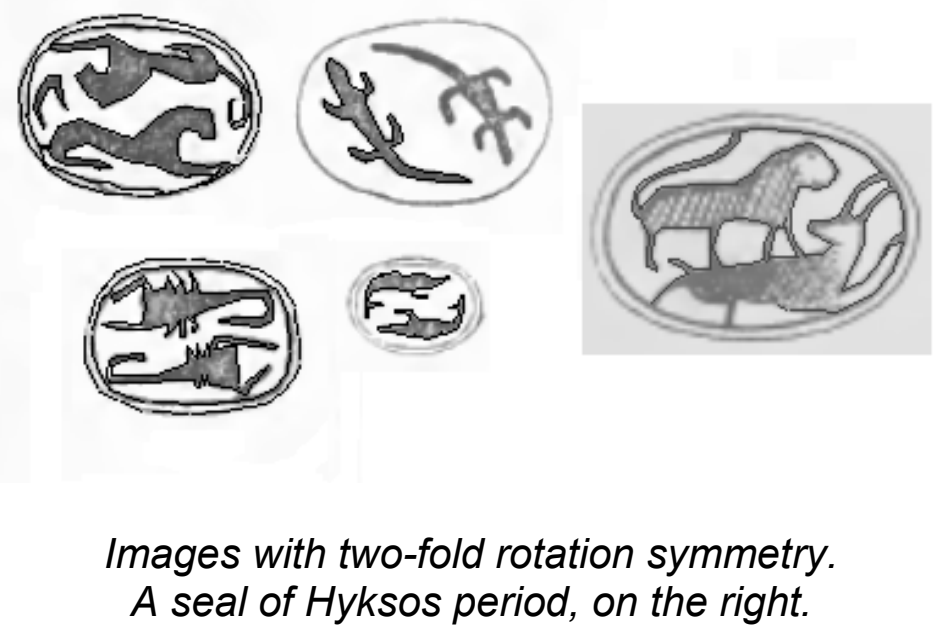

${ }^{19} \mathrm{~S}$. Davies, Minoan Seal Depicting Bull-Jumping in Action, at www.utexas.edu/courses/introtogreece/lect2/img6minseal.html 
The collection of the Egyptian Museum of Torino has scarabs with two scorpions arranged to have rotational and bilateral symmetries.
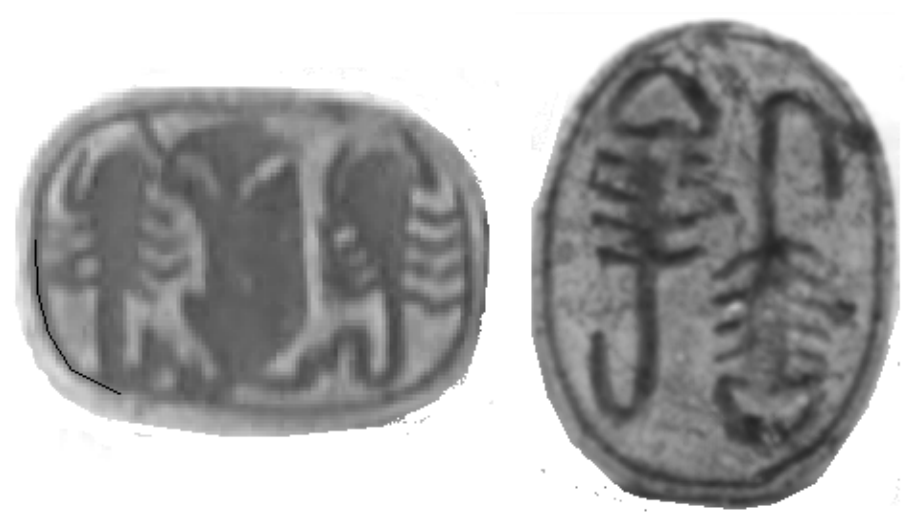

Images with bilateral symmetry on the left and rotational symmetry on the right (Egyptian Museum, Torino)

The collection possesses a quite unusual seal with two men, may be twins. This seal can be dated to 2200-2040 BC, the first intermediate period of Egypt. The former scarabs with human figures were developed during this period. The human figure was depicted with a linear style, as if it were composed by sticks $^{20}$. It would be interesting to analyse the back of this seal, to understand if also the back has symmetry.

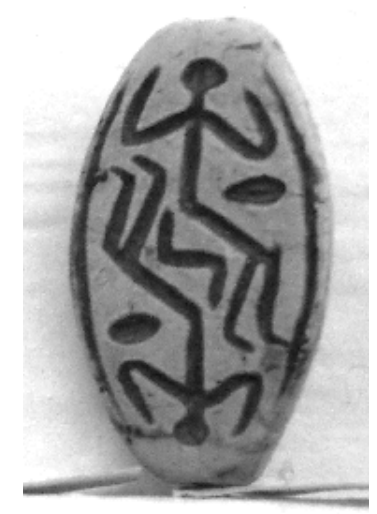

The twins at the Egyptian Museum of Torino.

${ }^{20}$ F. Magnarini, 2004 


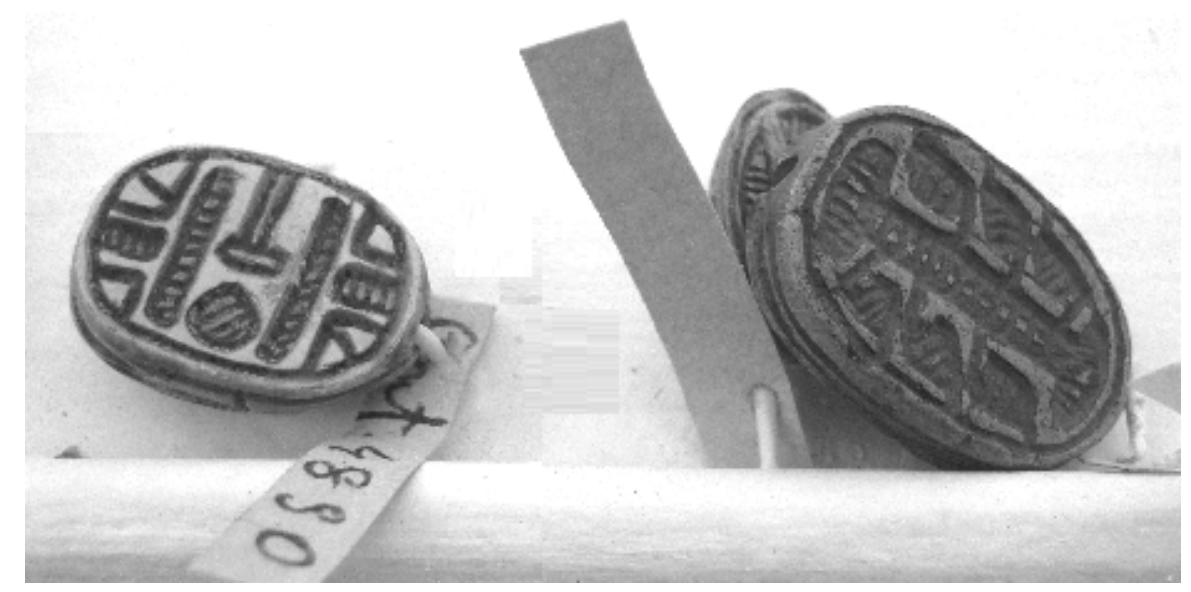

The rotational symmetry can be found in small details (the corners on the left, and the leaves on the right).

A huge number of Egyptian scarabs are engraved with coils and spiral, according to the style of the Middle Kingdom. Engraved patterns develop twofold, four-fold rotational or bilateral symmetries.

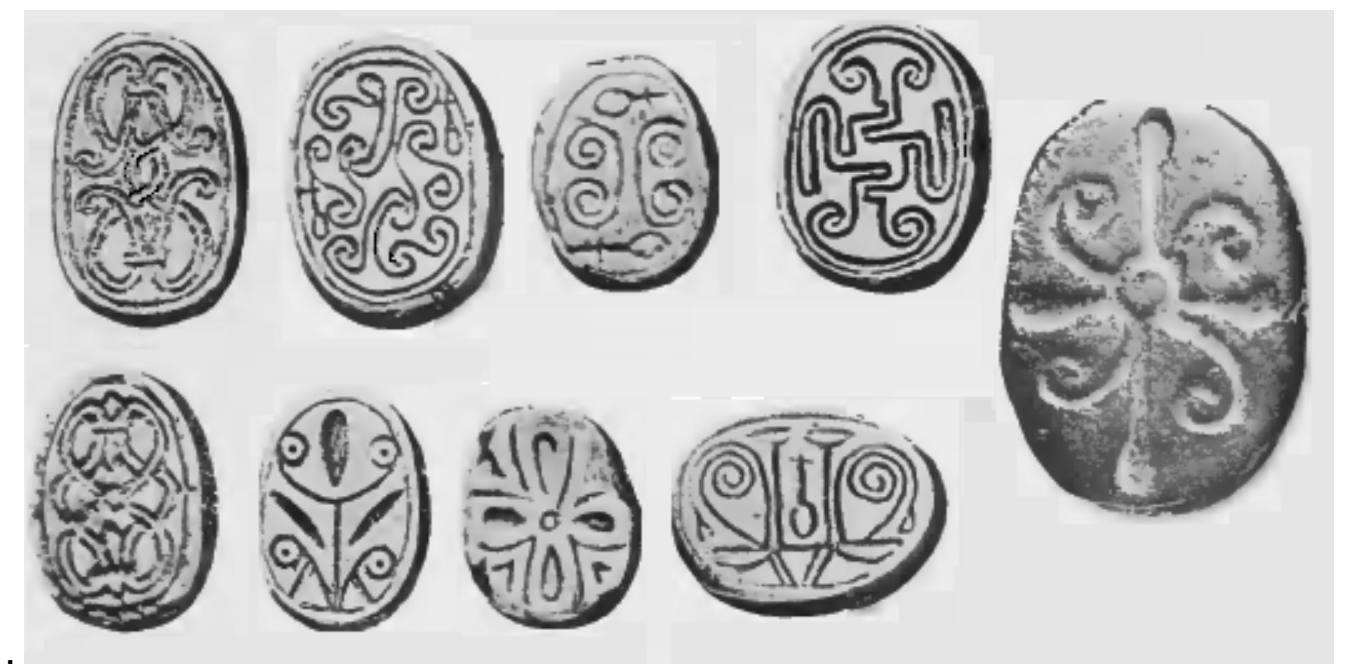

The two symmetries, rotational and bilateral of seals 
Observing these complex images on Scarabs, we are amazed about the knowledge of plane pattern symmetries of ancient Egyptian. Common opinion is that Egyptians had used all the 17 types of plane patterns. B. Grünbaum, who discussed the subject in 1984, considered this is as a misconception, because Egyptians appear to have missed the five symmetry groups, which have three-fold rotations. In fact, on scarab seals we do not observe three-fold symmetric images (to tell the true, it is difficult to arrange such images in an ovoid shape). Images with three-fold rotation can be observed on faience pottery.

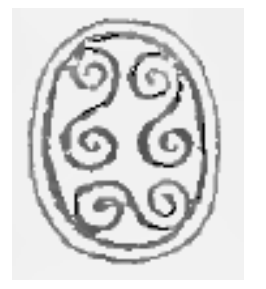

An attempt of three-fold symmetry, which is difficult to obtain in ovoid shapes.

P. Gerdes uses in his papers to ask why symmetry is such a common phenomenon in human culture. An easy answer for the bilateral one seems to be quite naturally associated with the fact that animals and human beings possess this symmetry. Symmetries, which are rare in nature, for instance the two-fold rotational symmetry, are nevertheless quite common amongst us. According to Gendes these symmetries can naturally arise in solving problems involved in weaving activities.

He reached this conclusion in studying entanglements of fibres to create baskets or textiles. We can extrapolate an interesting consequence: the use of symmetries in human artefacts is not a mere copy of natural objects. Symmetries in images started as a creative human action in very ancient times, without the conscious use of geometry. 


\section{References}

D. Ben-Tor, The Scarab: A Reflection of Ancient Egypt, Jerusalem, The Israel Museum, Jerusalem, 1989.

W.M. Flinders Petrie, Amulets, Martin Press, London, 1994

W. M. Flinders Petrie, Scarabs and cylinders with names. School of Archaeology in Egypt, London, 1917

P. Gerdes, On ethno-mathematical research and symmetry. Symmetry in a kaleidoscope, Symmetry Cult. Sci., 1(2), 154,1990

P. Gerdes, Fivefold symmetry and (basket) weaving in various cultures, in I. Hargittai Editor, Fivefold Symmetry, World Scientific, Singapore, 1992.

B. Grünbaum, The emperor's new clothes: full regalia, G-string, or nothing?, Math. Intelligencer, 6(4), 47, 1984

K.H. Hall, Catalogue of Egyptian scarabs, etc., in the British Musuem, Royal scarabs, British Museum, London, 1913

F. Magnarini, Catalogo ragionato di una collezione di scarabei-sigillo egizi, BAR International Series 1241, Oxford, 2004

P.E. Newberry, Scarab-shaped seals, Archibald Constable and Co., London, 1907

A. Sparavigna, Symmetries in Images on Ancient Seals, CogPrints, University of Southampton, ID6221, 2008

J. Ward, The sacred beetle: a popular treatise on Egyptian scarabs in art and history, John Murray, London, 1902 


\section{Conventional Egyptian chronology}

The conventional chronology is based on the rulers of ancient Egypt.

Protodynastic Period, Dynasty 0 circa 3100-2920

Scorpion I c.3200 BC

Double Falcon c.3200 BC

Ny-Hor c.3200 BC

Hat-Hor c.3200 BC

Pe-Hor c.3200 BC

Hedj-Hor c.3200 BC

Iry-Hor c.3150 BC

Ka c.3100 BC

Crocodile c.3100 BC

King Scorpion c.3100 BC

Narmer c.3100 BC

Early Dynastic Period

1st Dynasty 2920-2770

2nd Dynasty $2770-2650$

\section{Old Kingdom}

3rd Dynasty

4th Dynasty, among the kings of this dynasty we have

Sneferu 2575-2551

Khufu (Cheops) 2551-2528

Khafre (Chephren) 2520-2494

Menkaure (Mycerinus) 2490-2472

5th Dynasty

6th Dynasty

7th Dynasty 2150-2134

8th Dynasty

First Intermediate Period 2134-2040

9th and 10th Dynasties 2135-1986

11th Dynasty 2134-2040

Middle Kingdom 2040-1640

11th Dynasty

12th Dynasty 1991-1783

\section{Second Intermediate Period}

13th Dynasty

14th Dynasty (Egyptologist Donald B. Redford has suggested that these were ancestors of the Hyksos dynasty).

Hyksos 15th Dynasty 1633-1525

Sinai 16th Dynasty 
Thebes 17th Dynasty 1606-1539

\section{New Kingdom}

18th Dynasty

Ahmose I (Nebpehtyre) 1550 BC - 1525 BC

Amenhotep I (Djeserkare) 1525 BC - 1504 BC

Thutmose I (Akheperkare) 1504 BC - 1492 BC

Thutmose II Akheperenre) 1492 BC - 1479 BC

Thutmose III (Menkheperre) 1479 BC - 1425 BC

Hatshepsut (Maatkare) 1479 BC - 1457 BC

Amenhotep II (Akheperure) 1427 BC - 1401 BC

Thutmose IV (Menkheperure) 1401 BC - 1391 BC

Amenhotep III (Nebmaatre) 1391 BC - 1353 BC

Akhenaten (Neferkheperure-waenre) 1353 BC - 1334 BC

Smenkhkare (Ankhkheperure) 1336 BC - 1334 BC

Tutankhamun (Nebkheperure) 1334 BC - 1325 BC

Kheperkheprure Ay 1325 BC - 1321 BC

Horemheb (Djeserkheperure) 1321 BC - 1292 BC

19th Dynasty

Ramesses I 1292 - 1290

Seti I 1290 - 1279

Ramesses II (the "Great") 1279 - 1213

Merneptah 1213 - 1203

Amenmesse 1203 - 1199

Seti II $1199-1193$

Siptah $1193-1187$

Twosret $1187-1185$

20th Dynasty

Setnakhte 1186 BC - 1183 BC

Ramesses III 1183 BC - 1152 BC

Ramesses IV 1152 BC - 1146 BC

Ramesses V 1146 BC - 1142 BC

Ramesses VI 1142 BC - 1134 BC

Ramesses VII 1134 BC - 1126 BC

Ramesses VIII 1129 BC - 1125 BC

Ramesses IX 1125 BC - 1107 BC

Ramesses X 1107 BC - 1103 BC

Ramesses XI 1103 BC - 1072/1069 BC

\section{Third Intermediate Period}

Tanite 21st Dynasty

Theban 21st Dynasty

22nd - 25th Dynasty

Early Kings of Sais from 715 to 664

Late Period

26th Dynasty 
